Portland State University

PDXScholar

\title{
What Matters for Financial Development? Capital Controls, Institutions, and Interactions
}

\author{
Menzie David Chinn \\ University of Wisconsin-Madison \\ Hiro Ito \\ Portland State University, ito@pdx.edu
}

Follow this and additional works at: https://pdxscholar.library.pdx.edu/econ_fac

Part of the International Economics Commons

Let us know how access to this document benefits you.

\section{Citation Details}

Chinn, Menzie D., and Hiro Ito. "What matters for financial development? Capital controls, institutions, and interactions." Journal of development economics 81.1 (2006): 163-192.

This Working Paper is brought to you for free and open access. It has been accepted for inclusion in Economics Faculty Publications and Presentations by an authorized administrator of PDXScholar. Please contact us if we can make this document more accessible: pdxscholar@pdx.edu. 
NBER WORKING PAPER SERIES

\title{
WHAT MATTERS FOR FINANCIAL DEVELOPMENT? CAPITAL CONTROLS, INSTITUTIONS, AND INTERACTIONS
}

\author{
Menzie D. Chinn \\ Hiro Ito \\ Working Paper 11370 \\ http://www.nber.org/papers/w11370
NATIONAL BUREAU OF ECONOMIC RESEARCH
1050 Massachusetts Avenue
Cambridge, MA 02138
May 2005

Helpful comments were received from the co-editor Carlos Vegh, an anonymous referee, Joshua Aizenman, Michael Hutchison, Carl Walsh, Frank Warnock, Tom Willett, participants at the Kennedy School Luncheon on International Economic Policy, the USC development seminar, and the UCSC brown bag. We also thank Ashok Mody and Dennis Quinn for providing data. Financial support of faculty research funds of UC Santa Cruz are gratefully acknowledged.The views expressed herein are those of the author(s) and do not necessarily reflect the views of the National Bureau of Economic Research.

(C2005 by Menzie D. Chinn and Hiro Ito. All rights reserved. Short sections of text, not to exceed two paragraphs, may be quoted without explicit permission provided that full credit, including $\odot$ notice, is given to the source. 
What Matters for Financial Development? Capital Controls, Institutions, and Interactions Menzie D. Chinn and Hiro Ito

NBER Working Paper No. 11370

May 2005

JEL No. F36, F43, G28

\begin{abstract}
We extend our earlier work, focusing on the links between capital account liberalization, legal and institutional development, and financial development, especially that in equity markets. In a panel data analysis encompassing 108 countries and twenty years ranging from 1980 to 2000, we explore several dimensions of the financial sector. First, we test whether financial openness can lead to equity market development when we control for the level of legal and institutional development. Then, we examine whether the opening of the goods sector is a precondition for financial opening. Finally, we investigate whether a well-developed banking sector is a precondition for financial liberalization to lead to equity market development and also whether bank and equity market development complements or substitutes. Our empirical results suggest that a higher level of financial openness contributes to the development of equity markets only if a threshold level of general legal systems and institutions is attained, which is more prevalent among emerging market countries. Among emerging market countries, a higher level of bureaucratic quality and law and order, as well as the lower levels of corruption, increases the effect of financial opening in fostering the development of equity markets. We also find that the finance-related legal/institutional variables do not enhance the effect of capital account opening as strongly as the general legal/institutional variables. In examining the issue of the sequencing, we find that the liberalization in cross-border goods transactions is found to be a precondition for capital account liberalization. Our findings also indicate that the development in the banking sector is a precondition for equity market development, and that the developments in these two types of financial markets have synergistic effects.
\end{abstract}

Menzie D. Chinn

Department of Economics

University of Wisconsin

7470 Social Science Building

1180 Observatory Drive

Madison, WI 53706-1393

and NBER

mchinn@lafolette.wisc.edu
Hiro Ito

Department of Economics

Portland State University

1721 SW Broadway

Portland, OR 97201

ito@pdx.edu 


\section{Introduction}

Recent years have witnessed a surge of interest in issues surrounding globalization, including financial globalization. A series of financial crises in the 1990s rekindled the debates over the effects of removing capital controls, which led many observers to reconsider the balance between the costs and benefits of financial liberalization (Kaminsky and Schmukler, 2001a,b, 2002; Schmukler, 2003). ${ }^{1}$

Many studies have adopted the position that capital account liberalization can affect economic development through financial development; specifically, liberalized financial markets may contribute to developing financial markets that provide funds to borrowers who may have productive investment opportunities. ${ }^{2}$ Theory suggests that capital account liberalization can lead to development of financial systems through several channels. First, financial liberalization may mitigate financial repression in protected financial markets, allowing the (real) interest rate to rise to its competitive market equilibrium (McKinnon, 1973; Shaw, 1973). Second, removing capital controls allows domestic and foreign investors to engage in more portfolio diversification. These two points can be summarized as that financial liberalization may reduce the cost of capital and increasing its availability for the borrowers. Stulz (1999) shows that financial globalization reduces the cost of equity capital because of the reduction in the expected returns to compensate risk as well as in agency costs (also, Henry, 2000; Bekaert et al., 2000, 2001). Third, not least, the liberalization process usually increases the efficiency level of the financial system by weeding out inefficient financial institutions and creating greater pressure for a reform of the financial infrastructure (Claesens et al., 2001; Stulz, 1999; Stiglitz 2000). Such an improvement in financial infrastructure may alleviate information asymmetry, decreasing adverse selection and moral hazard, and further raising the availability of credit.

The link between financial liberalization and financial development is not unequivocal, however. It is often argued that to benefit from more open cross-border financial transactions,

\footnotetext{
${ }^{1}$ In this study we do not discuss the merits of capital controls in the context of financial crises. For a review, see Aizenman (2002). Kletzer and Mody (2000) survey the debate in the context of "self-protection policies" for emerging markets. Ito (2004) investigates the correlation between financial liberalization and the output performance of crisis-hit economies.

${ }^{2}$ See for instance Leahy, et al. (2001) for OECD-specific results. Klein and Olivei (2001) document the linkage between financial development and economic growth for developed countries, and its absence for less developed countries. Spiegel (2001) examines an APEC sample, while Arteta, Eichengreen and Wyplosz (2001) document the fragility of many of these group-specific results. IMF (2001, Chapter 4) surveys both the growth and finance, and finance and liberalization literatures. For the most recent review on finance and growth, refer to Quinn, et al. (2002)
} 
financial systems need to be equipped with reasonable legal and institutional infrastructure.

In economies where the legal system does not clearly define property rights or guarantee the enforcement of contracts, the incentives for loan activities can be limited. Legal protections for creditors and the level of credibility and transparency of accounting rules are also likely to affect economic agents' financial decisions. ${ }^{3}$ Levine, Loayza, and Beck (2000) investigate whether the level of legal and regulatory determinants of financial development influences the development financial intermediary sector. La Porta, Lopez-de-Silanes, Shleifer, and Vishny (hereafter LLSV, 1997, 1998) argue that the national legal origin (whether English, French, German, or Scandinavian) strongly affects the legal and regulatory environment in financial transactions and explains cross-country differences in financial development. LLSV $(1997,1998)$ and Levine $(1998,2003)$ show that low levels of shareholder rights are associated with poorly developed equity markets (especially in French civil law countries). In contrast, Common law countries have high levels of shareholder rights with correspondingly high levels of equity market development (Claessens, et al., 2002 and Caprio, et al., 2003), and that greater creditor rights are positively associated with financial intermediary development. ${ }^{4}$

Clearly, the link between financial liberalization and financial development is of great importance to emerging market policymakers, and naturally, one needs to examine the effect of liberalizing cross-border financial transactions in the context the institutional setting. However, very little investigation has been made to shed light on the link in such a context. This is the topic of our study.

In this article, we extend our work (Chinn and Ito, 2002) focusing on the links between capital account liberalization, legal and institutional development, and financial development. Since our study is motivated by the development of equity markets through financial liberalization and its contribution to economic development among emerging market countries in the 1990s, our focus is on the effect of capital account liberalization on the development of equity markets among less developed and emerging market countries. We conduct a panel data analysis encompassing 108 countries (including 21 industrialized countries and 31 emerging market countries) and twenty

\footnotetext{
${ }^{3}$ For the analysis of legal development on financial development, see Beck and Levine (2004), Claessens, et al. (2002), Caprio, et al. (2003), and Johnson, et al. (2002). For a general discussion on the importance of legal and institutional foundations for financial development, see Beim and Calomiris (2001) and Stultz (1999).

${ }^{4}$ Rajan and Zingales (2003), on the other hand, question the link between legal origins and cross-country difference in financial development, and instead stress the important role of political forces in shaping policies toward financial markets and their development.
} 
years ranging from 1980 to 2000. In addition to searching for the effects of each set of factors, we examine the oft-discussed issue of the sequence of liberalization. It has been often argued that countries need to liberalize their goods market prior to liberalizing financial sector (McKinnon, 1991). Also, in order for financial systems to reap the benefit of financial liberalization, the systems themselves need to be developed up to a certain level, suggesting the importance of a sequence of liberalization within the financial sector (Martell and Stulz, 2003). To test these claims, we examine whether the opening of the goods sector is a precondition for financial opening, and furthermore, investigate whether a well-developed banking sector is a precondition for financial liberalization to lead to equity market development. Additionally, we explore whether bank and equity market development complements or substitutes.

Our empirical results suggest that a higher level of legal and institutional development contributes both directly and in an interactive manner with financial openness to the development of equity markets, but only if a country is equipped with a reasonable level of legal and institutional development, which is more prevalent among emerging market countries than developing countries. A higher level of bureaucratic quality and law and order, as well as the lower levels of corruption, may enhance the effect of financial opening in fostering the development of equity markets. We also find that, among emerging market countries, the overall level of finance-related legal/institutional development increases stock market trading volumes and enhances the effect of financial openness. However, the finance-related legal/institutional variables do not exhibit as strong an effect as the general legal/institutional variables. In examining the issue of the sequencing, we find that the liberalization in cross-border goods transactions is found to be a precondition for capital account liberalization, in a result similar to that obtained by Aizenman and Noy (2004). Our findings also indicate that the development in the banking sector is a precondition for equity market development, and that the developments in these two types of financial markets have interactive effects.

\section{An Econometric Analysis of Openness, Institutions and Financial Development}

The link between capital account openness, financial development, and legal/institutional environment has been investigated by Chinn and Ito (2002). In this study, we demonstrated that financial systems with a higher degree of legal/institutional development on average benefit more 
from financial liberalization than those with a lower one. Furthermore, the positive effect of legal/institutional development seems to flow primarily from the degree of shareholder protection and accounting standards. In what follows, we extend our previous study by employing updated data and also exploring more questions related to the link between capital account openness and financial development. More specifically, we will investigate the issues relevant to the sequence of liberalization between financial and goods cross-border flows and the sequence of development in banking and equity markets.

\subsection{The Empirical Specification}

First, we reexamine the long-term effect of capital account openness on financial development in a model that controls for the level of legal and institutional development. The model is specified as:

(1) $F D_{t}^{i}-F D_{t-5}^{i}=\gamma_{0}+\rho F D_{t-5}^{i}+\gamma_{1} K_{A O P E N_{t-5}^{i}}+\gamma_{2} L^{i}+\gamma_{3}\left(L^{i} \times K A O P E N_{t-5}^{i}\right)+X_{t-5}^{i} \Gamma+u_{t}^{i}$,

where $F D$ is a measure of financial development; KAOPEN is a measure of financial openness; $\boldsymbol{X}$ is a vector of economic control variables; and $L^{i}$ refers to a measure of legal or institutional development.

For the capital openness variable, we use the Chinn-Ito index which is described in greater detail in a later section and the data appendix. The vector $\boldsymbol{X}$ contains macroeconomic control variables that include log per capita income in PPP terms, the inflation rate, and trade openness, measured as the ratio of the sum of exports and imports to GDP. In this analysis, the set is kept fairly small so as to retain some interpretability of the correlations. Log per capita income is included as there is a long literature ascribing financial deepening, aside from the role of regulation, to the increasing complexity of economic structures associated with rising income. The inflation rate is included because it may distort decision-making. ${ }^{5}$ In particular, moderate to high inflation may discourage financial intermediation, and encourage saving in real assets. Finally, trade openness is included as an ad hoc control; many empirical studies find a correlation of trade openness with any number of economic variables. The relationship between trade openness and financial openness will be investigated more thoroughly in a later section.

\footnotetext{
${ }^{5}$ Since in most cases, the volatility of inflation rises with the inflation rate, the inflation rate could be proxying for either or both of these effects.
} 
A series of regressions is conducted for each of the financial development variables $(F D)$, which include private credit creation $(P C G D P)$, stock market capitalization $(S M K C)$, stock market total value (SMTV), all measured as a ratio of GDP, and stock market turnover (SMTO). Also for the series of regressions with different financial development measures, we also include each of the nine legal/institutional variables and its interactive term with the capital account openness index. The nine legal/institutional variables include those which are pertaining to the general development of legal systems or institutions as well as those pertaining particularly to financial transactions. Further discussions about the legal/institutional variables are presented in the data section.

In order to avoid problems of endogeneity associated with short term cyclical effects, we specify our model as a growth rate on levels regression, akin to a panel error-correction model with non-overlapping data. That is, we only sample data every five years between 1980 and 2000, and use the five-year average growth of the level of financial development as the dependent variable and the "initial conditions" for time-variant explanatory variables, including the initial level of the financial development indicator, for each five-year panel. ${ }^{6}$

\subsection{The Data}

The data are drawn from a number of sources, primarily the World Bank's World Development Indicators, the IMF's International Financial Statistics, and the databases associated with Beck, Demirgüc-Kunt, and Levine (2000). The analysis is based upon data originally recorded at an annual frequency, over the 1970-2000 period, covering 108 countries. Details are reported in Appendix 1.

\subsubsection{Financial Development Measures}

The measures of financial development are extracted from the dataset of Beck, Demirgüc-Kunt, and Levine (2000). PCGDP, the ratio of private credit from deposit money banks to the private sector, represents the overall development in private banking markets. ${ }^{7}$ While this variable is examined for purposes of comparison, our focus is primarily on the development of equity markets development, for which we use three variables as the measures: SMKC (stock market capitalization), SMTV (total value of stocks traded), and SMTO (stock market turn over

\footnotetext{
${ }^{6}$ Time fixed effects are also included in the model to control for possible time-specific exogenous shocks.

7 While many researchers use M2 or liquidity liabilities (M2Y and LLY in our data set), we only report results for $P C G D P$ as our focus is on equity market development, and also because the correlation between $M 2 Y$ or $L L Y$ and
} 
ratio). We can consider $S M K C$ as the measure of the size of equity markets and SMTV and SMTO as the measure of the activeness of equity markets.

Regarding the measurement issues surrounding financial development, we must make two more notes. First, in this study, we do not look into offshore markets as part of financial development, and therefore, focus merely on the development of domestic equity markets. Although we have witnessed through the Asian financial crisis that some emerging market countries such as Korea and Thailand tried to complement their domestic markets by developing offshore markets and allowing foreign investors, mostly hedge funds, to actively engage, there have not developed so much literature regarding these issues, mainly owing to the recentness of the development of hedge funds and offshore markets. ${ }^{8}$ Furthermore, the relationship between onshore and offshore funds has not been rigorously investigated (except for Kim and Wei, 2002) due to data unavailability. ${ }^{9}$ Hence, we do not attempt to link offshore funds to domestic equity markets.

Secondly, our analysis does not consider the effect of capital account liberalization on the overseas listings by international firms. Several authors have discussed the process of emerging market companies "migrating" to mature markets by listing their shares and trading in New York or other major stock markets. The implications of this process is under debate. Claessens et al. (2002) and Levine and Schmukler (2003) provide evidence that migration of trading from domestic to international markets allows firms to reap from international portfolio diversification gains, while contributing to the shrinkage of local markets. On the other hand, Karolyi (2003) shows that cross-listings in the form of American Depositary Receipts (ADRs) neither facilitate nor hinder local market development, but that it "may be an outcome of the declining market conditions and not a cause of them." 10 Given the ambiguity of the effects, and data limitations, we focus on the development of domestic equity markets.

PCGDP is quite high ( $84.9 \%$ and $81.9 \%$, respectively),.

${ }^{8}$ The exceptions include Fung and Hsieh (2001), their other works, Brown and Goetzmann (2001), and Brown et al. (1998).

${ }^{9}$ Kim and Wei study the behavior of the Korean offshore market, and find that the Korean offshore funds trade more aggressively than onshore markets; but they do not engage in positive feedback trading unlike their onshore counterparts; and that they do herd, but not so much as the onshore funds in the U.S. or U.K. which tends to herd more during a crisis.

${ }^{10}$ Sarkissian and Schill (2002) show that internationalization of trading is constrained by geographical and institutional/cultural familiarity, making the gains from international portfolio diversification small. Their analysis shows that overseas listings are not conducted to "overcome investor home bias," but "reflect the bias." 
Table 1 reports the growth rates of financial development measured in the variables used in this study. Inspection of the table reveals that during the 1990s, all subsample groups experienced the most rapid development in equity markets, measured along several dimensions, including size $(S M K C)$ and transactions activity (SMTV and SMTO). This is true despite the retrenchment in the equity markets of less developed and emerging market countries during the second half of the decade. Hence, the development of equity markets has progressed - albeit in a halting fashion - for the last three decades.

\subsubsection{Capital Openness Index - the Chinn-Ito Index}

It is well known that it is extremely difficult to measure the extent of openness in capital account transactions (e.g., Eichengreen, 2002; Edison et al., 2002). Although many measures exist to describe the extent and intensity of capital account controls, the consensus is that such measures fail to fully capture the complexity of real-world capital controls for a number of reasons. ${ }^{11}$

First, conventional measures of quantifying capital controls (or financial openness) sometimes fail to account for the intensity of capital controls. The most prominent example of such measures include binary variables based upon the IMF's categorical enumeration reported in Annual Report on Exchange Arrangements and Exchange Restrictions (AREAER). ${ }^{12}$ Second, IMF-based variables are too aggregated to depict the intricacy of actual capital controls. Capital controls can differ depending on the direction of capital flows (i.e., inflows or outflows) as well as the type of financial transactions targeted. ${ }^{13}$ Thirdly, it is almost impossible to distinguish between de jure and de facto controls on capital transactions. Capital control policies are often implemented without explicit policy goals to control the volume and/or type of capital flows. Conversely, as Edwards (1999) discusses, it is often the case that the private sector circumvents capital account restrictions, nullifying the expected effect of regulatory capital controls. Therefore, researchers

\footnotetext{
${ }^{11}$ See Edison and Warnock (2001), Edwards (2001), and Edison et al. (2002) for discussions and comparisons of various measures on capital restrictions. Dooley (1996) provides an extensive literature review and Neely (1999) presents a descriptive overview of capital controls.

${ }^{12}$ There are binary variables created based on a set of "on-off" clarification, which includes an indicator variable for the existence of multiple exchange rates $\left(k_{1}\right)$; restrictions on current account $\left(k_{2}\right)$; capital account transactions $\left(k_{3}\right)$; and a variable indicating the requirement of the surrender of export proceeds $\left(k_{4}\right) . k_{3}$ is the one often used for capital controls. In 1996, the classification method in the AREAER changed and these four categories became more disaggregated as an effort to reflect the complexity of capital controls policies.

${ }^{13}$ This issue is somewhat alleviated by the recent disaggregation in the AREAER of the $k 3$ category into 13 subcategories. Johnston and Tamirisa (1998) created the time series of capital controls based on the new 13 disaggregated components in the AREAER. However, their data series are not sufficiently long; it only covers years after 1996. Most recently, Miniane (2004) constructed a set of indices to measure the intensity of capital controls, based on an approach akin to Johnston et al., but extending the data back to 1983 for 34 countries.
} 
often refer to financial integration among countries and interpret it as de facto restrictions on capital transactions (See De Gregorio (1998) and Rajan (2003)).

In this study, we rely upon the capital account openness index, KAOPEN developed by Chinn and Ito (2002). This index is the first principle component of the four IMF binary variables discussed above. ${ }^{14}$ One of the merits of the KAOPEN index is that it attempts to measure the intensity of capital controls, insofar as the intensity is correlated with the existence of other restrictions on international transactions. By the nature of its construction, one may argue that the KAOPEN index measures the extensity of capital controls because it may not directly refer to the stringency of restrictions on cross-border transactions, but to the existence of different types of restrictions. However, measuring the extensity of capital controls may be a good proxy to the measure of intensity of capital controls. ${ }^{15}$ This point can be made more concrete by considering a country with an open capital account. It may still restrict the flow of capital by limiting transactions on the current account restrictions or other systems such as multiple exchange rates and requirements to surrender export proceeds. Alternatively, countries that already have closed capital accounts might try to increase the stringency of those controls by imposing other types of restrictions (such as restrictions on current account and requirements for surrender of trade proceeds) so that the private sector cannot circumvent the capital account restrictions. Another merit of this index is its wide coverage (more than 100 countries) for a long time period (1970 through 2000). ${ }^{16}$ Appendix 2 explains how KAOPEN is constructed.

Table 2 presents the averages of KAOPEN and IMF binary variables for the full sample period of $1970-2000$ and each decade. Not surprisingly, the group of industrialized countries have maintained a high level of capital account openness over the full sample period while emerging market countries seem to have slightly more open capital accounts than less developed

\footnotetext{
${ }^{14}$ For the extension of the four binary classifications after 1996, we followed Mody and Murshid (2005).

${ }^{15}$ One might think of the Quinn (1997) index as the measure of the intensity of capital controls. The Quinn index is a composite measure of financial regulation that ranges from 0 to 14, with 14 representing the least regulated and most open regime. The bulk of the index is based upon Quinn's coding of the qualitative information contained in the AREAER pertaining to $k_{2}$ and $k_{3}$, augmented by information regarding whether the country in question has entered into international agreements with international organizations such as the OECD and EU. A complete tabulation for the OECD members exists, but the coverage for the less developed countries is much less extensive. The correlation between the Quinn index and the Chinn-Ito index is found to be $83.9 \%$, suggesting that KAOPEN is proxying the intensity of capital controls. The correlation between the aforementioned index by Miniane (2004), which is based on more disaggregated AREAER information on capital controls, and the Chinn-Ito index is found to be $80.2 \%$.

${ }^{16}$ The Quinn index is available for the OECD members between 1958 and 1997, but the coverage for the less developed countries is limited to certain years $(1958,1973,1982,1988$, and 1997).
} 
countries. ${ }^{17}$ Interestingly, both industrialized and emerging market countries achieved much more rapid financial liberalization between the 1980s and 1990s than less developed countries, especially making the difference between emerging market and less developed countries in capital account openness become quite large by the 1990s.

\subsubsection{Measures of Legal/Institutional Development}

The legal/institutional variables can be categorized into two groups. The first group contains the measures related to the general development of legal systems and institutions, namely LEGAL1, Corrupt, LAO, and BQ. LEGAL1 is the first principal component of the other three variables, and we treat this variable as a representative measure of the general level of legal/institutional development. ${ }^{18}$ Corrupt, $L A O$, and $B Q$ measure the level of corruption, law and order, and the quality of the bureaucratic system, respectively. All of these data series included in LEGAL1 are obtained from the ICRG database. In these indexes, higher values indicate better conditions. The data series are available for the period of 1984 through 1997, but are included as the period-average in order to maintain comparability with the LEGAL2 variables. The summary statistics for the LEGAL1 variables are reported in Table 3. In the table, we can observe that the wide gap in the level of legal and institutional development between industrialized and less developed countries, and also that emerging market countries have achieved a higher level of legal development within the group of less developed countries.

The second group of legal variables - CREDITOR, ENFORCE, SHRIGHTS, and ACCOUNT - pertain specifically to financial transactions, and are obtained from LLSV (1998). CREDITOR refers to the level of creditor protection, while ENFORCE is an index of the effectiveness of the legal system in enforcing contracts. SHRIGHTS is a measure of shareholder protection, and ACCOUNT is an index of the comprehensiveness of company reports. LEGAL2 is the first standardized principal component of the four variables, and therefore depicts the overall development of the legal system governing financial transactions. ${ }^{19}$ The summary statistics for these $L E G A L 2$ variables are reported in Table 4.

Before discussing the results, we make the following two observations. The first pertains to the temporal nature of these institutional variables. Although we use panel data specifications in

\footnotetext{
17 The cross-sectional average of $K A O P E N$ for the full sample period is zero by construction.

${ }^{18}$ The first eigenvector for $L E G A L 1$ was found to be (Corrupt, $\left.L A O, B Q\right)^{\prime}=(0.574,0.580,0.578)$, indicating that the variability of $L E G A L I$ is not merely driven by any particular series.

${ }^{19}$ The first eigenvector for LEGAL2 was found to be (Creditor, Enforce, Shrights, Account $)^{\prime}=(0.206,0.670,0.095$,
} 
the following analyses, the data on legal/institutional development are cross-sectional in nature, i.e., they are time-invariant. However, the inclusion of these time-invariant factors do not pose a substantial problem for our analysis, since these characteristics represented by the legal/institutional variables are likely to change only very slowly. ${ }^{20}$ Moreover, we focus mainly on the effect of financial openness on financial development, but not the effect of legal/institutional development per se. In other words, rather than shedding light on how the development of institutions and legal systems affects financial development, we examine how the effect of financial openness changes depending upon the "environment" of institutions and legal systems. Therefore, time-variation of the legal/institutional variables is not critical to our study.

The second issue is sample size. While the original panel encompasses 108 countries, the data set based on LLSV spans less than 50 countries. $^{21}$ There is minimal impact on the coverage of the industrialized countries, but the size of the LDC sample is substantially reduced.

Consequently, our LDC sample in this portion of the analysis essentially becomes the emerging market group previously defined. ${ }^{22}$ Hence, for the regressions with the first group of legal/institutional variables (i.e., LEGAL1, Corrupt, $L A O$, and $B Q$ ), we will present results for the full sample and the subsamples for less developed countries (LDC) and emerging market countries (EMG) whereas for those with the second group of legal variables, we report results for the full sample and a subset titled the "LDC/EMG" category, which is mainly composed of EMG countries.

\subsection{Empirical Results}

The regression results for the model specified in equation (1) are reported in Tables 5-1 through 5-4. We focus on the coefficients of $K A O P E N_{t-5}$ (first row), the legal variable (second row), and the interactive term between the legal variable and $K A O P E N_{t-5}$ (third row). Our observations will mainly focus on the regressions with equity market development measures and

$0.707)^{\prime}$.

${ }^{20}$ Stulz (1999) and Stiglitz (2000) argue that financial globalization puts pressure on governments to improve legal systems and infrastructure for financial markets. However, to our knowledge, there is no empirical evidence for the causality. Also, as previously mentioned, the ICRG legal variables are available since 1984, which also creates practical data constraints for us to use time-varying variables for legal and institutional development.

${ }^{21}$ More specifically, the data set contains LEGAL data for 38 countries, CREDITOR for 46 countries, ENFORCE for 48 countries, SHRIGHTS for 47 countries, and ACCOUNT for 40 countries.

${ }^{22}$ The LLSV cross-sectional data set used for this paper includes only three countries which are not either industrialized or emerging market countries by our definition. 
especially those of less developed and emerging market countries. ${ }^{23}$

Table 5-1 reports the regression results for the models with $L E G A L 1$. We can see that when the regressions are controlled for the general development of legal systems and institutions $(L E G A L 1)$, financial openness $\left(K A O P E N_{t-5}\right)$ contributes to financial development in equity markets, measured by stock market total values, in both LDC and EMG subsamples. In these models, the interactive effect between financial openness and legal development is also detected. Significant coefficients for the interactive term are also found in the models with other measures of equity market development for both LDC and EMG subsamples. However, we must be careful about how to interpret the overall effect of capital account openness because it depends on the level of legal development. ${ }^{24}$ That is, given equation (1), the total effect of financial openness can be shown as:

\section{Total Effect of KA openness ${ }^{i}=\left(\gamma_{1}+\gamma_{3} \bar{L}\right) K_{\text {KOPEN }}^{i}{ }_{t-5}$,}

where $\bar{L}$ is the mean of a measure of legal development. For example, when we examine the regression specifications for the financial development measured in stock market total value for LDC and EMG groups in Table 5-1 (columns [7] and [11]), the total effect of a one-unit increase in $K A O P E N$ is calculated to be -0.0006 for less developed countries and 0.005 for emerging market countries if we use each subsample's average of $L E G A L 1,-0.74$ for the former group and -0.28 for the latter. Thus, although the estimated coefficients for KAOPEN and the interaction terms are not significantly different between LDC and EMG groups, the difference in the general level of legal and institutional development makes the effect of $K A O P E N$ on equity market development quite different between the subsample groups; while opening capital accounts, on average, leads to a lower rate of development in equity markets among less developed countries, it leads to a more rapid rate of equity market development for emerging market countries. As another example, Peru, an emerging market country in our sample, increased its financial openness level from -1.84 to 2.27 between 1990 and 1995. Given its $L E G A L 1$ level of -1.65 , the increase in financial openness

\footnotetext{
${ }^{23}$ The definition of emerging market countries relies upon the International Financial Corporation's (IFC) indices. The group of emerging market countries in this study refers to the countries which were included in either IFC's Global, Investible, or Frontier Index as of 1995. By this definition, there are 31 EMG countries in our sample. However, as has been mentioned previously, for the regressions with the LEGAL2 (financial legal) variables, because of data availability, there is no distinction between LDC and EMG, but there is a subgroup LDC/EMG.

${ }^{24}$ In case of the regressions with $L E G A L 1$, the fact that the variable can be negative for a lower value (see Table 3 ) also contributes to the complexity in the interpretation.
} 
would reduce the growth rate of stock market total value by $4.1 \%$ point annually. Argentina, another EMG country, experienced a smaller increase of 3.15 in its KAOPEN variable (from -1.16 to 2.00), but because its LEGAL1 level is -0.175 , higher than Peru's, its SMTV is predicted to grow at an additional $1.9 \%$ annually. Given that SMTV grew at $3.00 \%$ annually for emerging market countries during the 1990s (Table 1), this acceleration in the growth rate is significant. Thus, opening capital accounts can be effective for financial development only if a country has attained a threshold level of legal and institutional development.

Table 6 makes this point clear. In this table, row [A] shows the total effect of a one-unit increase in $K A O P E N$ calculated using the estimates from the regression model with stock market total value for the subsample of less developed countries, evaluated at the average values of the legal variable for LDC and EMG (shown in row [B]). Row [C] shows the threshold level of the legal variable, above which a one-unit increase in capital account openness has a positive impact on equity market development. Thus we can conclude that, in order for capital account openness to contribute to the development of equity markets, countries must be possessed of a level of legal/institutional development greater than $L E G A L 1=-0.68$. Hence, emerging market countries (whose average value of LEGAL1 -0.28 exceeds the -0.68 threshold), will on average benefit from opening their capital accounts. On the other hand, less developed countries will hamper their equity market development by opening capital accounts. In our dataset, Tunisia has a value of LEGAL1 closest to the threshold level (its value is -0.683 ). The countries marginally above the threshold level include India and Morocco ( -0.561 and -0.566 , respectively) among others, while those closely below include Mexico and Iran ( -0.793 and -0.738 , respectively) among others.

Figure 1 depicts this clear difference in the correlation between capital account openness and equity market development. The upper scatter diagram (a) shows the relationship between the five-year change in the KAOPEN level five years prior to the time period (i.e., change between $t-10$ and $t-5)$ and the level change in $S M T V$ between $t-5$ and the contemporary time period $(t)$ for the countries whose $L E G A L 1$ value is above the threshold level, while diagram (b) is for those with lower $L E G A L 1$ variables than the threshold. Not surprisingly, we can observe that, for the countries with above-threshold levels of general legal or institutional development, KAOPEN and SMTV have a positive relationship. For the countries with below-threshold levels of legal development, there is no discernable relationship between capital account opening and equity market development. Also, in these countries, equity markets appear to be far from active 
regardless of the degree of financial liberalization.

Table 5-2 summarizes the results from the regressions that are run with each of the components of $L E G A L 1$ (i.e., Corrupt, $L A O$, and $B Q$ ) included individually and interactively. For the sake of brevity, the table shows only the coefficients of the financial openness variable, the legal/institutional variable, and the interaction term. Across the different models with different measures of financial development, the significance of the estimated coefficients appears to be qualitatively the same as those of the regressions with LEGAL1. Table 6, again, helps our interpretation of the overall effect of KAOPEN for the models with SMTV. Generally, we can surmise that liberalizing capital accounts may lead to development in equity markets only when the measures against corruption or law and order are higher than the threshold levels (52.2 and 54.5 , respectively). In other words, their measures need to be as well-established as in emerging market countries in order to reap the benefit of capital account liberalization. When we control for the level of bureaucratic quality, financial openness seems to leads to financial development among both less developed and emerging market countries (because of both subsample groups' higher average values than the threshold level), but its effect is higher for the latter group. Interestingly, we can observe that the coefficient of $K A O P E N_{t-5}$ alone has a negative sign wherever the interactive term has a significant coefficient, suggesting that opening financial markets alone may lead to underdevelopment of equity markets, but it can be avoided only if the countries are equipped with a reasonable level of legal/institutional development.

When we focus on the effect of legal development relating particularly to financial transactions (LEGAL2 and LLSV variables), the findings are not as decisive as in the previous cases (results shown in Tables 5-3 and 5-4). ${ }^{25}$ Using LEGAL2 as the legal/institutional variable (Table 5-3) in the LDC/EMG subgroup, its interactive effect with LEGAL2, and the LEGAL2 level term are significant in the determination of the development in stock market total value. Table 6 shows that the total effect of financial openness is positive on average in the LDC/EMG subgroup (i.e., the subgroup's average level of legal development is higher than the threshold level). In other models for the LDC/EMG subgroup, however, neither financial openness nor its interactive term seems to affect banking or equity market development in a significant fashion.

Among the components of the financial legal development variable (LEGAL2), shown in

\footnotetext{
${ }^{25}$ As previously discussed, due to the data availability of the LLSV variables, there is only one subsample for non-industrialized countries, which we call LDC/EMG.
} 
Table 5-4 (which again only shows the coefficients of interest), the level of creditor protection seems to be an important factor for financial development in both banking and equity sectors while no interactive effect is detected. When contract enforcement is used as the legal/institutional variable, in all models with equity market development, we can detect a positive interactive effect and a negative solo effect of the level of financial openness. ${ }^{26}$ Among the models with shareholder protection, the level of share holder protection seems to matter for stock market capitalization while the level of financial openness contributes to stock market turnover. The models using accounting standards as the legal/institutional measure do not indicate any effect of financial openness on financial development.

Our findings suggest that in order for financial openness to help develop equity markets, the level of legal and institutional development is crucial. If a country tries to develop its equity markets while it is not equipped with well-developed legal systems or institutions, opening capital accounts may even harm the development of equity markets. Also, we find that it is the development of general legal systems and institutions, not of those specific to financial transactions, that is crucial for a country to benefit from opening its financial markets.

\subsection{Robustness Checks}

Here, we examine whether our baseline results are sensitive to outliers. Concerns about the impact of outliers flows from two issues. First, in addition to the usual measurement error present in macroeconomic data, it is likely that the data for financial development is subject to even greater measurement errors. Second, these financial development indicators may unintentionally capture financial bubbles, although the use of five year changes may serve to mitigate this concern. As a point of reference, it is useful to note that in many studies of lending booms as financial crises indicators, changes in lending or stock market sizes over a shorter window, of between 2 to 4 years are, often used. ${ }^{27}$ Nonetheless, we investigate whether the regression results are being distorted by data outliers. In order to conserve space, we merely summarize the results and our observations below.

First, using the original annual data, we exclude the observations of financial development variables if their annual growth rates are two standard deviations away from the mean in both

\footnotetext{
${ }^{26}$ The patterns of the significance of the coefficients are no coincidence. By construction, the components of ENFORCE are closest to LEGAL1 variables as shown in data appendix.

27 See Corsetti, Pesenti, and Roubini (1998), Chinn, Dooley and Shrestha (1999), Kaminsky (2003), Kaminsky, Lizondo and Reinhart (1998), Kaminsky and Schmukler (2001b), and Sachs, Tornell and Velasco (1996).
} 
directions, and re-estimate the same sets of regressions. ${ }^{28}$ The exclusion of outliers shrinks the observation size by a relatively small degree, about $0-11 \% .^{29}$ Generally, in the re-estimated results (not reported), the magnitude of the estimated coefficients often becomes smaller, but so do the standard errors, especially for the models with stock market related measures for the LDC and EMG subgroups. Therefore, not only does the statistical significance of the coefficients remain qualitatively unchanged, but in addition some of the coefficients which were previously insignificant become significant.

Interestingly, in many models the adjusted $R$-squared increases. This is most apparent in the models with LEGAL2 and ACCOUNT. In this analysis for the LDC/EMG group, the coefficient of $L E G A L 2$ is now significant for the model with $S M K C$, and both the KAOPEN variable and the interactive term are statistically negative and positive, respectively, for the models with SMKC and SMTV. The same exercise is then repeated, but increasing the range of outlier exclusion by dropping the observations if their annual growth rates are larger than one and a half standard deviations away from the mean in both directions. This exclusion shrinks the sample size quite substantially (sometimes as much as $40 \%$ ), although the results are largely unchanged. The fit and the significance of the coefficients even improves for the models for the LDC/EMG with LEGAL2 and ACCOUNT. Two conclusions flow from this exercise. First, the key findings of the analysis are not driven by outliers. Second, some of the findings related to the legal/institutional variables could have even been obscured by the effects of outliers.

\subsection{Reverse Causality?}

One may reasonably ask if financial development is what allows countries to implement financial liberalization policy, rather than the reverse. While we have worked with non-overlapping, five-year window panels in order to mitigate problems associated with simultaneity, it may still be worthwhile to investigate whether countries need to develop their financial systems before undertaking capital account liberalization. Conversely, if we can show that reverse causality is irrelevant, that will be evidence that countries can develop their financial markets by exogenously deciding to open their financial markets.

\footnotetext{
${ }^{28}$ Since we are dealing with a set of non-overlapping five year panels, in essence the only data for 1980, 1985, 1990, 1995 , and 2000 are affected by the removal of outliers.

${ }^{29}$ Exclusion of the outliers takes place more for the models with stock market total value and stock market turnover than those with private credit creation and stock market capitalization, which reflects that the former group are more subject to market volatility than the latter. The rate of exclusion is generally higher for the subgroup of emerging
} 
To explore the above question, we change the specification in equation (1) by exchanging the places of $K A O P E N_{t-5}$ and financial development measures (PCGDP, SMKC, SMTV, and $S M T O$ ); the left-hand side variable is now the five-year average growth in KAOPEN while the independent variables of our focus now becomes the financial development variable and the interactive terms between the legal/institutional variables and the financial development variables. We run regressions specified as follows, using non-overlapping data and including each of the legal/institutional variables:

(2) $\mathrm{KAOPEN}_{t}^{i}-\mathrm{KAOPEN}_{t-5}^{i}=\phi_{0}+\varphi K A O P E N_{t-5}^{i}+\phi_{1} F D_{t-5}^{i}+\phi_{2} L^{i}+\phi_{3}\left(L^{i} \times F D_{t-5}^{i}\right)+X_{t-5}^{i} \Phi+v_{t}^{i}$.

The coefficient of our interest is $\phi_{1}$; A significantly positive $\phi_{1}$ would indicate that the above OLS regression results entail simultaneous causality, i.e., financial development leads to financial openness. The regression results (not reported) show that across the regressions with different financial development measures as well as legal/institutional variables, the coefficients, $\phi_{1}$ 's, are mostly statistically insignificant or significantly negative, either of which is against the null hypothesis that financial development leads to financial openness. The significantly negative $\phi_{1}$ 's are found in the regressions that have the dependent variable of the equity market development measures. One of the possible explanations for the negative $\phi_{1}$ may be that a rapid growth in equity markets, in terms of the size of the markets $(S M K C)$ or the liquidity of the markets (SMTV or SMTO) is sometimes associated with financial crises, and that policy makers lower the degree of financial openness during periods of crisis (Ito, 2004). At the very least, we can conclude that our estimation results are not subject to obvious simultaneity issues (as in Bekaert, et al.,2001).

\section{Investigating the Sequence of Liberalization}

\subsection{Trade and Capital Account Liberalization}

One suggestive result we must discuss is the frequent finding of statistically significant and positive coefficients on the trade openness variable in the above estimation results based on equation (2). ${ }^{30}$ To the extent that our trade openness variable reflects trade liberalization, our results are germane to the question if trade openness is a precondition for financial opening. This is 
the optimal sequence question, which has been raised by many, including McKinnon (1991). In fact, liberalization in goods markets is often claimed to be a precondition for financial liberalization policy (Tornell et al., 2004).

We empirically explore this hypothesis by employing a simple model that accounts for the determinants of financial openness or restrictions. As stated in equation (3), we model financial openness is the function of government budget surplus, international reserves, trade openness, and per capita GDP. ${ }^{31}$

(3) $\mathrm{KAOPEN}_{t}=\xi_{0}+\xi_{1} \mathrm{KAOPEN}_{t-5}+\xi_{2}$ TradeOpen $_{t-5}+Z_{t-1 \mathrm{lt}-5} \Xi+v_{t}$,

where $Z_{t-1 \mid t-5}$ is a vector of macroeconomic control variables, namely, government budget surplus, international reserves, and per capita GDP. ${ }^{32}$ The rationale for using these macro variables follows the past literature. Grilli and Milesi-Ferretti (1995) showed that a higher level of restrictions on capital flows is empirically linked to higher rates of inflation, a higher share of seigniorage in total taxes, lower real interest rates, and a higher share of government consumption in GDP. Their finding implies that capital controls appear to have strong fiscal implications, i.e., countries with a less developed tax system tend to implement capital controls as the source of government revenue as well as the remedy to capital flows caused by the inflation-driven distortions in the financial markets. In investigating the empirical determinants of capital controls, Johnston and Tamirisa (1998) find that countries tend to implement capital controls, the more prevalent the balance of payments concerns are, the higher real interest rates and real exchange rates, ${ }^{33}$ and the larger the size of the government deficit as a share of GDP. We select two variables - the government budget

\footnotetext{
${ }^{30}$ Again, due to space considerations, the regression results are not reported. They are available upon request.

${ }^{31}$ The empirical model also controls for regional differences by regional dummies. In Glick, Guo and Hutchison (2004), an empirical model of capital account liberalization is proposed. Our set of explanatory variables overlaps, but does not match, theirs. In part the difference arises from their more empirically oriented motivation for model selection.

${ }^{32}$ The variable for gross international reserves is a proxy to the balance of payments situation of the countries and is measured by gross international reserves in months of imports. The lower gross reserves in months of imports, the higher prevalence of balance of payments concerns are. The data are extracted from the World Bank's World Development Indicators. Others have used international reserves as a ratio to M2 as a proxy to the balance of payments situation. The regression results shown in this paper are qualitatively unchanged if international reserves as a ratio to M2 are used.

33 Their theoretical prediction, which contrasts with that of Grilli and Milesi-Ferretti, is that countries use capital controls to pursue inconsistent internal and external balances simultaneously such as the case where outflow controls are implemented to avoid nominal currency deprecation pressures without tightening of monetary conditions. When such a threat of currency crisis arises, the real interest rates or real exchange rates tends to be higher. See Leblang (1997) for more discussions on the determinants of capital controls.
} 
surplus and international reserves - since they are most commonly argued as the determinants of capital controls. ${ }^{34}$ We also include per capita GDP to control for the level of development of the economic system. Since these variables are supposed to control for the general trend of macro variables, they are included as the 5-year average prior to the time period $t$ (as shown as $(t-1 \mid t-5)$ in the regression results table).

With these macro variables, we test whether trade openness is a precondition for financial opening by including a five-year lagged variable for the trade openness measure. Although we used in the previous analyses, opn, the sum of exports and imports divided by GDP, as the trade openness variable, we use a different variable to measure openness in trade flows. By construction, the variable opn measures the openness in good transactions in terms of not only economic factors but also regulatory measures such as tariffs and quotas. As such, we use another variable TRADEOPEN which is a reciprocal of the duties imposed on both imports and exports. ${ }^{35}$

In order to minimize the possibility of two-way causality, we employ a non-overlapping panel data analysis as we did in previous analyses. While the macro variables are included as the five-year average, both KAOPEN and TRADEOPEN are included as the initial conditions of each five-year panel. In the empirical analysis, we focus on the coefficient $\xi_{2}$ to see if the openness in goods trade can be a precondition for financial opening.

The first three columns of Table 7 report the regressions results. While the average budget surplus and GDP per capita enter significantly, but not international reserves, the trade openness variable seems to contribute to the level of financial openness in the full sample and the subsample for the less developed countries, indicating that the openness in goods transactions is a precondition for financial openness. Columns (4) through (6) of Table 7 show the results when we switch the places for KAOPEN and TRADEOPEN in the regression, in order to see whether the reverse causality also holds. ${ }^{36}$ We can see that in both the full sample and the subsamples, the

\footnotetext{
${ }^{34}$ In addition to the above variables, we attempted to include variables that refer to the government engagement in seigniorage, such as the inflation rate or the reserve ratio. However, these measures of seigniorage can cause multicollinearity in regression analysis due to its correlation with the level of government budget surplus, the reverse of which is often the reason for seigniorage. Therefore, we decided not to include seigniorage-related variables in our regression model.

${ }^{35}$ Import and export duties as a ratio to imports and exports, respectively, are available from the World Bank's WDI. The weighted average of these variables is calculated using the share of imports and exports in total trade and then subtracted from 100 to show the openness. Hence, the higher (or close to 100) TRADEOPEN is, the less duties imposed on trade flows in both directions, i.e., the more open trade flows are by regulation. Note the variable is included in $\log$ form.

${ }^{36}$ The variable for international reserves is not retained because it lacks a theoretical motivation.
} 
financial openness variable does not enter significantly. Hence, we can safely conclude that the more openness in goods transactions can lead to a more openness in capital account, but the reverse causality does not appear to be present, a result consistent with Tornell et al. (2004).

\subsection{Endogeneity and the Sequence of Liberalization}

Taking our cue from the results reported above, we implement two stage least squares (2SLS) estimation instrumenting the $K A O P E N_{t-5}$ variable in equation (1) with the initial conditions of financial and trade openness five years prior to the variable (i.e., 10-year lagged), as well as government budget surplus and GDP per capita as the five-year average prior to $t-5$ and regional dummies. ${ }^{37}$ If we can detect the effect of financial openness on financial development, we can present evidence that financial opening which is preceded by trade opening leads to financial development in a model where the level of legal/institutional development is controlled for.

The results of applying 2SLS to a model that controls for the general development level of legal systems and institutions (LEGAL1) are reported in Table 8. For the group of less developed countries, we can see that both the magnitude and the statistical significance of the estimated coefficients for the models with stock market capitalization $(S M K C)$ and stock market total value $(S M T V)$ increase. For the $S M K C$, the levels of both legal development and financial openness seem to be significant contributors to equity market development. When financial development is measured by stock market total value, in addition to the level effects of both financial openness and legal development, the interactive effect between the two is also identified. Similar results are also found in the group of emerging market countries. Given these results, we may conclude that financial opening succeeding trading opening leads to equity market development especially when it takes place in an economy with a reasonably developed legal system.

\section{Interactions of Banks and Equity Markets}

In this section, we investigate two questions. The first is whether the development of a banking sector a precondition for the development of an equity market? Second, does the development of one sector substitute or complement development in another?

\footnotetext{
${ }^{37}$ The international reserves variable is not included because of its insignificance in the previous analysis.
} 


\subsection{Sequencing in Financial Development}

We modify the basic regression model of equation (1) by adding a new term: the level of financial development in the alternative mode. For the regressions with equity market development, the initial level of banking development, private credit creation (PCGDP), in each five-year panel is included in the regression model whereas the initial level of equity market development, measured as stock market capitalization $(S M K C)$, is included in the regressions for banking development as a comparison. The new equation is now:

$$
\begin{aligned}
F D_{t}^{i}-F D_{t-5}^{i}=\gamma_{0}+\rho F D_{t-5}^{i}+\gamma_{1} \text { KAOPEN }_{t-5}^{i}+\gamma_{2} L^{i}+\gamma_{3}\left(L^{i} \times \text { KAOPEN }_{t-5}^{i}\right) \\
+\lambda_{0} \text { OtherFin }_{t-5}+X_{t-5}^{i} \Gamma+\varepsilon_{t}^{i}
\end{aligned}
$$

where OtherFin refers to $P C G D P$ for the regressions on equity market development and to $S M K C$ for the regression with $P C G D P$. As with the basic model, the regression is repeated for each of the financial development measures as the dependent variable and using different legal/institutional variables. Given the results from the previous section, we will only use the legal/institutional variables from the $L E G A L 1$ group.

The regression results are summarized in Table 9. This table contains only the estimated coefficients for OtherFin $_{t-5}\left(\lambda_{0}\right)$. While $S M K C_{t-5}$ never enters significantly for the models on banking development in both the full sample and the subsamples, the coefficient for $P C G D P_{t-5}$ is always significantly positive in the models with $S M K C$ and SMTV for the LDC subsample with all the legal/institutional variables. These results suggest that banking development is an important precondition for the development in equity markets among less developed countries, while, as expected, the development in equity markets does not seem to be a precondition for banking development in any countries.

\subsection{Complements or Substitutes?}

We now investigate the question of whether banking and equity markets are complements or substitutes. To do so, we make only one modification to the previous empirical model. Instead of the initial level of a different type of financial development, we include a new variable $\left(\right.$ OtherFD $\left.D_{t}^{i}-O t h e r F D_{t-5}^{i}\right)$ which is the five-year average growth of financial development in another sector. 


$$
\begin{aligned}
F D_{t}^{i}-F D_{t-5}^{i}=\gamma_{0}+\rho F D_{t-5}^{i}+\gamma_{1} \text { KAOPEN }_{t-5}^{i}+\gamma_{2} L^{i} & +\gamma_{3}\left(L^{i} \times K A O P E N_{t-5}^{i}\right) \\
& +\tau_{0}\left(\text { OtherFD }_{t}^{i}-\text { OtherFD }_{t-5}^{i}\right)+X_{t-5}^{i} \Gamma+\varepsilon_{t}^{i}
\end{aligned}
$$

As in the previous analysis, the regressions on equity market development includes the five-year average growth of PCGDP as $\left(O t h e r F D_{t}^{i}-O t h e r F D_{t-5}^{i}\right)$ and those with PCGDP includes the five-year average growth of $S M K C$. The estimator of our focus is now $\tau_{0}$; a significantly positive (negative) coefficient estimate indicates that developments in equity and banking sectors are complements (substitutes).

Table 10 displays the estimated coefficients for $\left(O \operatorname{ther} F D_{t}^{i}-O t h e r F D_{t-5}^{i}\right)$. Interestingly, in the LDC group with all the legal/institutional variables, both $\left(P C G D P_{t}^{i}-P C G D P_{t-5}^{i}\right)$ in the $S M K C$ model and $\left(S M K C_{t}^{i}-S M K C_{t-5}^{i}\right)$ in the PCGDP model are significantly positive. This means that for the group of less developed countries, the development in banking sector and that in equity markets are complementary to each other. Given the results in the previous section, while less developed countries may well be able to develop their financial markets by opening capital account if it is equipped with a reasonable level of legal/institutional development, banking development and equity market development seem to have synergistic effects.

\section{Concluding Remarks}

We began our empirical investigation by examining the nexus between capital account liberalization and financial development. Our key empirical results suggest that financial openness does contribute to equity market development, but only when a threshold level of general development of legal systems and institutions has been attained. Financial development measured as activity of the stock market - appears to depend upon capital account openness both individually and in interaction with the level of legal development. Interestingly, finance-specific legal institutions do not seem to fulfill the same role. Hence, we conclude that the general level of legal development matters more than the level of finance-specific legal/institutional development. These results are robust to the presence of outliers in the data and simultaneity.

We also obtain a series of other results. First, we find that the opening of goods markets is a precondition for financial opening. When the financial openness variable is instrumented with trade openness, the contribution of the general level of legal development still remains significant. 
This finding could be interpreted as evidence that an increase in trade openness is a prolog to financial openness, and thence to financial development.

Second, using a specification that controls for the level of legal and institutional development, we show that the development of the banking sector is a precondition for the development in equity markets. Finally, developments in less developed country banking and equity markets have interacting effects that work in both directions. 


\section{References}

Aizenman, Joshua (2002). "Financial Opening: Evidence and Policy Options," NBER Working Paper No. 8900 (April).

Aizenman, Joshua and Noy, I. (2004). "Endogenous Financial Openness: Efficiency and Political Economy Considerations," Manuscript, University of California, Santa Cruz.

Arteta, Carlos, Barry Eichengreen and Charles Wyplosz (2001). "When does capital account liberalization help more than it hurts?" NBER Working Paper No. 8414 (August).

Beck, Thorsten, Asli Demirgüc-Kunt, and Ross Levine (2000). "A new database on financial development and structure," Policy Research Paper No. 2147 (Washington, D.C.: World Bank).

Beck, Torsten., and Ross Levine (2004). "Legal Institutions and Financial Development", in: Claude Menard and Mary Shirley, eds., Handbook of New Institutional Economics, Kluwer Dordrecht (The Netherlands).

Beim, David, and Charles W. Calomiris (2001). Emerging Financial Markets, (New York: McGraw Hill).

Bekaert, Geert, Campbell Harvey, and Lundblad, C (2001). "Does Financial Liberalization Spur Growth?” NBER Working Paper \#8245.

(2000). "Emerging Equity Market and Economic Development," NBER Working Paper No. 7763 (April).

Brown, Stephen J. and William N. Goetzmann (2001). "Hedge Funds With Style," EFA 2001 Barcelona Meetings; Yale ICF Working Paper No. 00-29.

Brown, Stephen J., William N. Goetzmann, and James M. Park (1998). "Hedge Funds and the Asian Currency Crisis of 1997," Yale School of Management Working Paper No. F-58.

Caprio, Gerald, Laeven, Luc, and Ross Levine (2003). "Governance and Bank Valuation." University of Minnesota, mimeo.

Chinn, Menzie, Michael P. Dooley and Sona Shrestha (1999). "Latin America and East Asia in the Context of an Insurance Model of Currency Crises," Journal of International Money and Finance 18(4) (August): 659-681.

Chinn, Menzie and Hiro Ito, (2002). "Capital Account Liberalization, Institutions and Financial Development: Cross Country Evidence" NBER Working Paper \#8967.

Claessens, Stijn, Simeon Djankv, Joseph Fan, Larry Lang (2002). "Expropriation of Minority Shareholders in East Asia," Journal of Finance 57.

Claessens, Stijn, Daniela Klingebiel and Sergio L. Schmukler (2002). "Explaining the Migration of Stocks from Exchanges in Emerging Economies to International Centers," Policy Research Working Paper Series \#2816.

Claessens, Stijn, Asli Demirgüc-Kunt, and Harry Huizinga (2001). "How Does Foreign Entry Affect Domestic Banking Markets?” Journal of Banking and Finance. 25, pp. 891 - 911. 
Corsetti, Giancarlo, Paolo Pesenti, and Nouriel Roubini (1998). "Paper Tigers? A Preliminary Assessment of the Asian Crisis. NBER Working Paper No. 6783 (November).

De Gregorio, José (1998), "Financial Integration, Financial Development and Economic Growth," mimeo (Department of Industrial Engineering, Universidad de Chile, July).

Dooley, Michael (1996). “A Survey of Literature on Controls of International Capital Transactions," IMF Staff Papers 43(4) (December): 639 - 87.

Edison, Hali J., Michael W. Klein, Luca Ricci, and Torsten Sløk, (2002). "Capital Account Liberalization and Economic Performance: A Review of the Literature," mimeo (Washington, D.C.: IMF, May).

Edison, Hali J. and Francis E. Warnock (2001). "A simple measure of the intensity of capital controls," International Finance Discussion Paper \#708 (Washington, D.C.: Board of Governors of the Federal Reserve System, September).

Edwards, Sebastian (2001). "Capital Mobility and Economic Performance: Are Emerging Economies Different?” NBER Working Paper No. 8076 (January).

(1999). "How Effective are Capital Controls?” Journal of Economic Perspectives 13(4) (Fall): 65-84.

Eichengreen, Barry (2002). "Capital Account Liberalization: What Do the Cross-Country Studies Tell Us?" The World Bank Economic Review (March).

Fung, William and David A. Hsieh (2001). "The Risk in Hedge Fund Strategies: Theory and Evidence from Trend Followers," Review of Financial Studies, 14 (2001), 313-341.

Glick, Reuven, Xueyan Guo and Michael Hutchison (2004). "Currency Crises, Capital Account Liberalization and Selection Bias," University of California, Santa Cruz Working Paper \#04-14.

Grilli, Vittorio and Gian Maria Milesi-Ferretti (1995). "Economic Effects and Structural Determinants of Capital Controls," IMF Staff Papers 42(3) (September): 517 - 51.

Henry, Peter Blair (2000). "Stock Market Liberalization, Economic Reform and Emerging Market Equity Prices," Journal of Finance 55(2): 529-564.

International Monetary Fund (2001). World Economic Outlook (Washington, D.C.: IMF, September).

Ito, Hiro (2004). "Is Financial Openness a Bad Thing? An Analysis on the Correlation Between Financial Liberalization and the Output Performance of Crisis-Hit Economies" UCSC Working Paper Series.

Johnson, S., McMillan, J., and Woodruff, C. (2002) "Property Rights and Finance," American Economic Review 92, 1335 - 56.

Johnston, R. Barry and Natalia T. Tamirisa (1998). "Why Do Countries Use Capital Controls?" IMF Working Paper WP/98/181 (Washington, D.C.: IMF, December).

Kaminsky, Graciela (2003). "Varieties of Currency Crises” NBER Working Paper Series, \#10193.

Kaminsky, Graciela, Saul Lizondo, and Carmen Reinhart (1998). "Leading Indicators of Currency Crises," International Monetary Fund Staff Papers, 45, March, 1-48. 
Kaminsky, Graciela, and Sergio Schmukler (2002). "Short-Run Pain, Long-Run Gain: The Effects of Financial Liberalization,” World Bank Working Paper No. 2912.

(2001a). "Short- or Long-Run Integration: Do Capital Controls Matter," Brookings Trade Forum 2000 (Washington, DC: Brookings), pp. 125-178.

(2001b). "On Booms and Crashes: Financial Liberalization and Stock Market Cycles," mimeo, World Bank.

Karolyi, Andrew (2003). "The Role of ADRs in the Development of Emerging Equity Markets," Review of Economics and Statistics, forthcoming.

Kim, Woochan and Shang-Jin Wei (2002). "Offshore Investment Funds: Monsters in Emerging Markets?, Journal of Development Economics, 2002, Vol. 848.

Klein, Michael and Giovanni Olivei (2001). "Capital Account Liberalization, Financial Depth and Economic Growth," mimeo (Medford, MA: Tufts).

Kletzer, Kenneth and Ashoka Mody (2000). "Will Self-Protection Policies Safeguard Emerging Markets from Crises?" Managing Financial and Corporate Distress : Lessons from Asia, in Charles Adams, Robert E. Litan, and Michael Pomerleano (editors) (Washington, D.C. : Brookings Institution).

La Porta, R., Lopez-de-Silanes, F., Shleifer, A., Vishny, R.W. (1998). “Law and Finance,” Journal of Political Economy 106, p. 113 - 1155.

$1131-1150$.

(1997). "Legal Determination of External Finance,” Journal of Finance 52,

Leahy, Michael, S. Schich, G. Wehinger, F. Pelgrin, and T. Thorgeirsson (2001). "Contributions of financial systems to growth in OECD countries," OECD Economic Department Working Papers No. 280.

Leblang, David A. (1997). "Domestic and Systematic Determinants of Capital Controls in the Developed and Developing World” International Studies Quarterly, 41, p. 435 - 454.

Levine, Ross, (2003). "Bank-based or market-based Financial Systems: Which is Better?" Journal of Financial Intermediation 11, 398 - 428.

(1998). "Stock Markets, Banks, and Economic Growth," American

Economic Review 88, 537 - 58.

Levine, Ross, Norman Loayza and Thorsten Beck (2000). "Financial intermediation and growth: Causality and causes", Journal of Monetary Economics 46: 31-77.

Levine, Ross and Sergio L. Schmukler (2003). "Migration, Spillovers, and Trade Division: The Impact of Internationalization on Stock Market Liquidity," University of Minnesota Working Paper.

McKinnon, Ronald I. (1991). The Order of Economic Liberalization: Financial Control in the Transition to a Market Economy (Baltimore: Johns Hopkins University Press).

Brookings Institution).

(1973). Money and Capital in Economic Development (Washington, DC:

Martell, Rodolfo and René Stulz (2003) “Equity Market Liberalization as Country IPOs,” NBER 
Working Paper \#9481.

Miniane, Jacques (2004). "A New Set of Measures on Capital Account Restrictions," IMF Staff Papers 51(2).

Mody, Ashoka and Antu Panini Murshid (2005). "Growing up with Capital Flows," Journal of International Economics, 65, p. 249 - 266.

Neely, Christopher (1999). "An Introduction to Capital Controls," Review, Federal Bank of St. Louis, November/December.

Quinn, Dennis (1997). "The correlates of change in international financial regulation," American Political Science Review 91(3): 531-551.

Quinn, Dennis, A. Maria Toyoda and Carla Inclan (2002). "Does Capital Account Liberalization Lead to Economic Growth?: An Empirical Investigation" mimeo (Washington, D.C.: Georgetown University).

Rajan, Kishen S. (2003). "Financial Integration in Asean and Beyond: Implications for Regional Monetary Integration," presented at the ASEAN Roundtable 2003: "Roadmap to an ASEAN Economic Community," organized by the Institute of Southeast Asian Studies (Singapore: August 20-21).

Rajan, Raghuram G., Luigi Zingales (2003). "The Great Reversals: The Politics of Financial Development in the $20^{\text {th }}$ Century," Journal of Financial Economics 69.

Sachs, Jeffrey, Aaron Tornell, and Andres Velasco (1996). "Financial Crises in Emerging Markets: The Lessons from 1995" NBER Working Paper No. 5576 (May).

Sarkissian, Sergei and Michael J. Schill (2002). "The Overseas Listing Decision: New Evidence of Proximity Preference," McGill University Working Paper.

Schmukler, Sergio (2003). "Financial Globalization: Gains and Pain for Developing Countries," World Bank.

Shaw, Edward (1973). Financial Deepening in Economic Development (New York: Oxford University Press).

Stiglitz, Joseph (2000). "Capital Market Liberalization, Economic Growth, and Instability," World Development, 28:6, p. 1075 - 1086.

Stultz, René (1999). "Globalization, Corporate Finance and the Cost of Capital," Journal of Applied Corporate Finance, v12(3), 8-25.

Spiegel, Mark (2001). "Financial development and growth: Are the APEC nations unique?" Pacific Basin Working Papers PB01-04 (Federal Reserve Bank of San Francisco, June).

Tornell, Aaron, Frank Westermann, and Lorenza Martinez (2004). "The Positive Link Between Financial Liberalization, Growth, and Crises." NBER Working Paper No. 10293 (February). 


\section{Appendix 1: Data Definition and Sources}

Key to abbreviations:

BDL: Beck, Demirgüc-Kunt, and Levine (2000).

IFS: IMF, International Financial Statistics.

LLSV: La Porta, Lopez-de-Silanes, Shleifer, and Vishny (1998)

Mody: Personal communication from Ashok Mody, data based on AREAER

PWT: Penn World Table 6.1.

WDI: World Bank, World Development Indicators.

ICRG: International Country Risk Guide

\section{Macroeconomic Indicators}

current - Current account balance as a ratio to GDP, WDI

opn - openness to trade, (nominal exports plus imports)/nominal GDP

exports - national currency (from national account, 90c), IFS

imports - national currency (from national account, 98c), IFS

impduty - import duty as a ratio to imports, WDI

expduty - export duty as a ratio to exports, WDI

tradeopen - the weighted average of impduty and expduty calculated using the share of imports and exports in total trade and then subtracted from 100. The higher (or close to 100) tradeopen is, the less duties imposed on trade flows in both directions.

totalreserve - international reserves in months of imports, WDI

reserve_m 2 - international reserves as a ratio to $\mathrm{M} 2$, IFS

$r y p c=$ per capital real income in constant international

dollars, $P W T$

cpi - Consumer price index (64), IFS

infl - Inflation rate calculated using log differences of CPIs (64), IFS

gsur - government budget surplus (+) or deficit (-) as a ratio to GDP, WDI

\section{Regional Dummies}

$i d c$ - equals one if industrialized country, and zero, otherwise (See the list of countries)

emg - equals one if emerging market country, and zero, otherwise (See the list of countries)

asia - dummy for Asian countries

africa - dummy for African countries

westhem - dummy for the countries in the west

hemisphere

europe - dummy for European countries mideast - dummy for Middle East countries

\section{Financial Development Indicators}

$\boldsymbol{l l y}$ - Liquid Liability to GDP (LLY), currency demand and interest-bearing liabilities of banks and other financial intermediaries divided by GDP, BDL $S M K C$ - stock market capitalization ratio to GDP, BDL $\boldsymbol{S M T V}$ - stock market total value traded to GDP, BDL SMTO - stock market turn over ratio, BDL

$\boldsymbol{P C G D P}$ - Private Credit by Deposit Money Banks to GDP, BDL

$\boldsymbol{m} 2 \boldsymbol{y}$ - Ratio of M2 to nominal GDP, IFS

\section{Capital Controls Indicators}

$\boldsymbol{k}_{\boldsymbol{1}}$ - multiple exchange rates, Mody

$\boldsymbol{k}_{2}-$ restrictions on CA trans, Mody

$\boldsymbol{k}_{3}$ - restrictions on KA trans, Mody

$\boldsymbol{k}_{4}-$ surrender of exports proceeds, Mody

SHARE $\boldsymbol{k}_{3}$ - Share of a five-year period, the observed year and the last four years, when the capital account was open. Authors' calculations

KAOPEN - index for openness to capital account transactions. The first standardized principal components of $\mathrm{k}_{1}, \mathrm{k}_{2}, \mathrm{SHAREk}_{3}$, and $\mathrm{k}_{4}$. Authors' calculations.

quinn - Quinn financial liberalization indicator, Quinn. miniane - Miniane (2004) index on capital controls

\section{Legal Institutional Variables}

$\boldsymbol{L E G A L 1 ~ - ~ l e g a l ~ i n d e x , ~ t h e ~ f i r s t ~ p r i n c i p a l ~ c o m p o n e n t ~ o f ~}$ Corrupt, $L A O$, and $B Q$.

Corrupt - average of corruption in $1984-1997$.

$\boldsymbol{L A O}$ - average of Laworder in 1984 - 1997.

$\boldsymbol{B} \boldsymbol{Q}$ - average of $\boldsymbol{B} \boldsymbol{Q}$ in 1984 - 1997.

corruption - corruption index, ICRG.

lawoder - index for Law and order, ICRG. 
bureauc - index for bureaucratic quality, ICRG.

$\boldsymbol{L E G A L 2}$ - legal index, the first principal component of credit, enforce, shrights, and account, cross-sectional for 37 countries, LLSV

credit - index of creditor protection, composed of the variables which incorporate the automatic stay proposition on the assets of a failing firm ("noauto");

the continuation of the old managers in a reorganization process ("manages"); restrictions for going into reorganization ("restorg"); and the seniority system of secured creditors ("secured1"), cross-sectional for 44 countries, LLSV

enforce - index of the degree of law enforcement. Specifically, it is the average of "judsys" (efficiency of the judicial system), "rulelaw" (rule of law), "riskEx" (risk of expropriation), and "contrepu" (risk of contract repudiation), average over period $1982-1995$, cross-sectional for 46 countries, LLSV

shrights - the sum of "oneshvt" (one share-one vote), "bymail" (proxy by mail allowed), "noblock" (shares not blocked before meeting), "comulvt" (cumulative voting/proportional representation), "oppdmnty" (oppressed minority), "premprt" (preemptive right to new issues), and "esm" (\% of share capital to call an emergency shareholder meeting $<10 \%$ ), cross-sectional for 46 countries, LLSV

account - index of transparency and comprehensiveness of companies' (accounting) reports, based on data in 1990, cross-sectional for 38 countries, LLSV

cn - IMF country code, see the country list 
Country list (108 countries)

\begin{tabular}{|c|c|c|c|c|c|c|c|}
\hline 1 & 612 & DZA & Algeria & 57 & 443 & KWT & Kuwait \\
\hline 2 & 213 & $\mathrm{ARG}$ & Argentina ${ }^{\mathrm{e}}$ & 58 & 666 & LSO & Lesotho \\
\hline 3 & 193 & AUS & Australia ${ }^{\mathrm{i}}$ & 59 & 674 & MDG & Madagascar \\
\hline 4 & 122 & AUT & Austria $^{\mathrm{i}}$ & 60 & 676 & MWI & Malawi \\
\hline 5 & 313 & BHS & Bahamas, The & 61 & 548 & MYS & Malaysia $^{\mathrm{e}}$ \\
\hline 6 & 419 & BHR & Bahrain, Kingdom of ${ }^{\mathrm{e}}$ & 62 & 678 & MLI & Mali \\
\hline 7 & 513 & BGD & Bangladesh ${ }^{\mathrm{e}}$ & 63 & 181 & MLT & Malta \\
\hline 8 & 316 & BRB & Barbados & 64 & 682 & MRT & Mauritania \\
\hline 9 & 124 & BEL & Belgium $^{i}$ & 65 & 684 & MUS & Mauritius $^{\mathrm{e}}$ \\
\hline 10 & 339 & BLZ & Belize & 66 & 273 & MEX & Mexico $^{\mathrm{e}}$ \\
\hline 11 & 638 & $\mathrm{BEN}$ & Benin & 67 & 686 & MAR & Morocco $^{\mathrm{e}}$ \\
\hline 12 & 218 & BOL & Bolivia & 68 & 558 & NPL & Nepal \\
\hline 13 & 616 & BWA & Botswana $^{e}$ & 69 & 138 & NLD & Netherlands ${ }^{\mathrm{i}}$ \\
\hline 14 & 223 & BRA & Brazil $^{\mathrm{e}}$ & 70 & 196 & NZL & New Zealand ${ }^{\mathrm{i}}$ \\
\hline 15 & 748 & BFA & Burkina Faso & 71 & 278 & NIC & Nicaragua \\
\hline 16 & 618 & BDI & Burundi & 72 & 692 & NER & Niger \\
\hline 17 & 622 & CMR & Cameroon & 73 & 694 & NGA & Nigeria $^{\mathrm{e}}$ \\
\hline 18 & 156 & CAN & Canada $^{\mathrm{i}}$ & 74 & 142 & NOR & Norway ${ }^{\mathrm{i}}$ \\
\hline 19 & 626 & CAF & Central African Rep. & 75 & 449 & OMN & Oman \\
\hline 20 & 628 & TCD & Chad & 76 & 564 & PAK & Pakistan $^{\mathrm{e}}$ \\
\hline 21 & 228 & CHL & Chile $^{\mathrm{e}}$ & 77 & 283 & PAN & Panama \\
\hline 22 & 924 & $\mathrm{CHN}$ & China $^{\mathrm{e}}$ & 78 & 853 & PNG & Papua New Guinea \\
\hline 23 & 233 & COL & Colombia $^{\mathrm{e}}$ & 79 & 288 & PRY & Paraguay \\
\hline 24 & 634 & $\mathrm{COG}$ & Congo, Republic of & 80 & 293 & PER & Peru ${ }^{\mathrm{e}}$ \\
\hline 25 & 238 & CRI & Costa Rica & 81 & 566 & PHL & Philippines ${ }^{\mathrm{e}}$ \\
\hline 26 & 662 & CIV & Cote d'Ivoire ${ }^{\mathrm{e}}$ & 82 & 182 & PRT & Portugal i, e \\
\hline 27 & 423 & CYP & Cyprus & 83 & 714 & RWA & Rwanda \\
\hline 28 & 128 & DNK & Denmark $^{\mathrm{i}}$ & 84 & 456 & SAU & Saudi Arabia ${ }^{\mathrm{e}}$ \\
\hline 29 & 243 & DOM & Dominican Republic & 85 & 722 & SEN & Senegal \\
\hline 30 & 248 & ECU & Ecuador $^{\mathrm{e}}$ & 86 & 718 & SYC & Seychelles \\
\hline 31 & 469 & EGY & Egypt $^{e}$ & 87 & 724 & SLE & Sierra Leone \\
\hline 32 & 253 & SLV & El Salvador & 88 & 576 & SGP & Singapore $^{\mathrm{e}}$ \\
\hline 33 & 819 & FJI & Fiji & 89 & 199 & $\mathrm{ZAF}$ & South Africa ${ }^{\mathrm{e}}$ \\
\hline 34 & 172 & FIN & Finland $^{\mathrm{i}}$ & 90 & 184 & ESP & Spain $^{\mathrm{i}}$ \\
\hline 35 & 132 & FRA & France $^{\mathrm{i}}$ & 91 & 524 & LKA & Sri Lanka ${ }^{\mathrm{e}}$ \\
\hline 36 & 646 & GAB & Gabon & 92 & 734 & SWZ & Swaziland \\
\hline 37 & 648 & GMB & Gambia, The & 93 & 144 & SWE & Sweden ${ }^{\mathrm{i}}$ \\
\hline 38 & 134 & DEU & Germany $^{\mathrm{i}}$ & 94 & 146 & $\mathrm{CHE}$ & Switzerland ${ }^{\mathrm{i}}$ \\
\hline 39 & 652 & GHA & Ghana ${ }^{\mathrm{e}}$ & 95 & 463 & SYR & Syrian Arab Republic \\
\hline 40 & 174 & GRC & Greece ${ }^{i, e}$ & 96 & 738 & TZA & Tanzania \\
\hline 41 & 258 & GTM & Guatemala & 97 & 578 & THA & Thailand $^{\mathrm{e}}$ \\
\hline 42 & 263 & HTI & Haiti & 98 & 742 & TGO & Togo \\
\hline 43 & 268 & HND & Honduras & 99 & 369 & TTO & Trinidad and Tobago ${ }^{\mathrm{e}}$ \\
\hline 44 & 532 & HKG & Hong Kong ${ }^{\mathrm{e}}$ & 100 & 744 & TUN & Tunisia $^{\mathrm{e}}$ \\
\hline 45 & 176 & ISL & Iceland $^{\mathrm{i}}$ & 101 & 186 & TUR & Turkey $^{\mathrm{e}}$ \\
\hline 46 & 534 & IND & India $^{e}$ & 102 & 746 & UGA & Uganda \\
\hline 47 & 536 & IDN & Indonesia $^{\mathrm{e}}$ & 103 & 112 & GBR & United Kingdom $^{\mathrm{i}}$ \\
\hline 48 & 429 & IRN & Iran, Islamic Rep. of & 104 & 111 & USA & United States ${ }^{\mathrm{i}}$ \\
\hline 49 & 178 & IRL & Ireland ${ }^{\mathrm{i}}$ & 105 & 298 & URY & Uruguay \\
\hline 50 & 436 & ISR & Israel $^{\mathrm{e}}$ & 106 & 299 & VEN & Venezuela, Rep. Bol. $^{\mathrm{e}}$ \\
\hline 51 & 136 & ITA & Italy $^{\mathrm{i}}$ & 107 & 754 & ZMB & Zambia \\
\hline 52 & 343 & JAM & Jamaica $^{\mathrm{e}}$ & 108 & 698 & ZWE & Zimbabwe $^{\mathrm{e}}$ \\
\hline 53 & 158 & JPN & Japan $^{\mathrm{i}}$ & \multirow{4}{*}{\multicolumn{4}{|c|}{$\begin{array}{l}\mathrm{i} \text { - industrialized countries (IDC), } 22 \text { countries } \\
\text { e - emerging market countries (EMG), } 31 \text { countries } \\
\text { (Standard \& Poor, 2000) }\end{array}$}} \\
\hline 54 & 439 & JOR & Jordan $^{\mathrm{e}}$ & & & & \\
\hline 55 & 664 & KEN & Kenya $^{\mathrm{e}}$ & & & & \\
\hline 56 & 542 & KOR & Korea $^{\mathrm{e}}$ & & & & \\
\hline
\end{tabular}




\section{Appendix 2: The "Chinn-Ito" Index}

KAOPEN is an index to measure a country's degree of capital account openness. The dataset encompasses the time period of 1970-2000 for 108 countries. For a complete list of the countries, see the attached country list.

\section{Construction of KAOPEN}

$K A O P E N$ is based on the four binary dummy variables reported in the IMF's Annual Report on Exchange Arrangements and Exchange Restrictions (AREAER). These variables are to provide information on the extent and nature of the restrictions on external accounts for a wide cross-section of countries. These variables are:

- $\quad k_{1}$ : variable indicating the presence of multiple exchange rates;

- $k_{2}$ : variable indicating restrictions on current account transactions;

- $\quad k_{3}$ : variable indicating restrictions on capital account transactions; and

- $k_{4}$ : variable indicating the requirement of the surrender of export proceeds.

In order to focus on the effect of financial openness - rather than controls - we reverse the values of these binary variables, such that the variables are equal to one when the capital account restrictions are non-existent. Moreover, for controls on capital transitions $\left(k_{3}\right)$, we use the share of a five-year window (encompassing year $t$ and the preceding four years) that capital controls were not in effect $\left(\mathrm{SHAREk}_{3}\right)$.

$$
\operatorname{SHAREk}_{3, t}=\left(\frac{k_{3, t}+k_{3, t-1}+k_{3, t-2}+k_{3, t-3}+k_{3, t-4}}{5}\right)
$$

Then we construct an index for capital "openness" $\left(K A O P E N_{t}\right)$, which is the first standardized principal component of $k_{1 t}, k_{2 t} S H A R E k_{3}, k_{4 t}$. This index takes on higher values the more open the country is to cross-border capital transactions. By construction, the series has a mean of zero. The first eigenvector for KAOPEN was found to be $\left(S H A R E k_{3}, k_{1}, k_{2}, k_{4}\right)^{\prime}=(0.573,0.273,0.521$, 0.571 )', indicating that the variability of KAOPEN is not merely driven by the $\mathrm{SHAREk}_{3}$ series.

We incorporate the $k_{1, t}, k_{2, t}$, and $k_{4, t}$ variables in our KAOPEN variable instead of focusing on $k_{3}$ which refers to restrictions on capital account transactions. We believe the incorporation of $k_{1, t}, k_{2, t}$, and $k_{4, t}$ in this index allows us to more accurately capture the intensity of the capital controls. This point can be made more concrete by considering a country with an open capital account. It may still restrict the flow of capital by limiting transactions on the current account restrictions or other systems such as multiple exchange rates and requirements to surrender export proceeds. Alternatively, countries that already have closed capital accounts might try to increase the stringency of those controls by imposing $k_{1}, k_{2}$, and $k_{4}$ types of restrictions so that the private sector cannot circumvent the capital account restrictions.

Clearly, the measurement of the extent of capital account controls is a difficult enterprise. Many researchers have tried to capture the complexity of real-world capital controls, with varying degrees of success, and varying degrees of coverage. For reviews and comparisons of various measures on capital controls, refer to Edwards (2001), Edison et al. (2002) and Eichengreen (2002). 
Table 1: Growth rates of PCGDP, SMKC, SMTV, and SMTO $1970-2000$ and decades

\begin{tabular}{|c|c|c|c|c|}
\hline & \multicolumn{4}{|c|}{ Growth rates of } \\
\hline & $\begin{array}{c}\text { Private Credit } \\
\text { Creation } \\
(\text { PCGDP })\end{array}$ & \begin{tabular}{|c|} 
Stock Market \\
Capitalization \\
$($ SMKC $)$
\end{tabular} & $\begin{array}{c}\text { Stock Market } \\
\text { Total Value } \\
\text { (SMTV) }\end{array}$ & \begin{tabular}{|c|} 
Stock Market \\
Turnover \\
(SMTO)
\end{tabular} \\
\hline \multicolumn{5}{|c|}{$1970-2000$} \\
\hline Full & $0.87 \%$ & $1.93 \%$ & $1.87 \%$ & $2.47 \%$ \\
\hline IDC & $1.74 \%$ & $2.96 \%$ & $3.67 \%$ & $3.45 \%$ \\
\hline LDC & $0.61 \%$ & $1.32 \%$ & $0.84 \%$ & $1.87 \%$ \\
\hline EMG & $0.91 \%$ & $1.49 \%$ & $1.09 \%$ & $2.49 \%$ \\
\hline \multicolumn{5}{|c|}{$1970-1979$} \\
\hline Full & $0.62 \%$ & $0.47 \%$ & $0.18 \%$ & $0.35 \%$ \\
\hline IDC & $0.77 \%$ & $-0.22 \%$ & $0.25 \%$ & $-0.35 \%$ \\
\hline LDC & $0.57 \%$ & $1.70 \%$ & $0.11 \%$ & $1.85 \%$ \\
\hline EMG & $0.70 \%$ & $1.29 \%$ & $0.09 \%$ & $1.55 \%$ \\
\hline \multicolumn{5}{|c|}{$1980-1989$} \\
\hline Full & $0.68 \%$ & $1.52 \%$ & $1.33 \%$ & $1.98 \%$ \\
\hline IDC & $1.99 \%$ & $2.89 \%$ & $2.25 \%$ & $3.61 \%$ \\
\hline LDC & $0.30 \%$ & $0.53 \%$ & $0.70 \%$ & $0.78 \%$ \\
\hline EMG & $0.49 \%$ & $0.70 \%$ & $0.82 \%$ & $1.16 \%$ \\
\hline \multicolumn{5}{|c|}{$1990-2000$} \\
\hline Full & $1.08 \%$ & $3.33 \%$ & $3.72 \%$ & $3.81 \%$ \\
\hline IDC & $1.95 \%$ & $5.59 \%$ & $7.51 \%$ & $4.40 \%$ \\
\hline LDC & $0.85 \%$ & $2.27 \%$ & $1.99 \%$ & $3.53 \%$ \\
\hline EMG & $1.35 \%$ & $2.66 \%$ & $3.00 \%$ & $5.14 \%$ \\
\hline \multicolumn{5}{|c|}{$1995-2000$} \\
\hline Full & $1.58 \%$ & $3.03 \%$ & $4.81 \%$ & $5.08 \%$ \\
\hline IDC & $3.10 \%$ & $9.50 \%$ & $12.06 \%$ & $6.52 \%$ \\
\hline LDC & $1.19 \%$ & $0.25 \%$ & $1.66 \%$ & $4.45 \%$ \\
\hline EMG & $1.78 \%$ & $-0.39 \%$ & $2.83 \%$ & $7.30 \%$ \\
\hline
\end{tabular}

Notes: For the data description, refer to section 2.2.1 as well as Appendix 1. The original data are extracted from the updated version of the Beck, Demirgüc-Kunt, and Levine (2000) dataset. 
Tale 2: Averages of KAOPEN, $k 1, k 2 \mathrm{k3}$, and $k 4$ $1970-2000$ and decades

\begin{tabular}{|c|c|c|c|c|c|}
\hline & \multicolumn{5}{|c|}{ Averages of } \\
\hline & KAOPEN & $k 1$ & $k 2$ & $k 3$ & $k 4$ \\
\hline \multicolumn{6}{|c|}{$1970-2000$} \\
\hline Full & 0.000 & 0.796 & 0.501 & 0.311 & 0.258 \\
\hline IDC & 1.125 & 0.903 & 0.830 & 0.499 & 0.571 \\
\hline LDC & -0.288 & 0.769 & 0.416 & 0.264 & 0.177 \\
\hline EMG & -0.255 & 0.743 & 0.396 & 0.276 & 0.194 \\
\hline \multicolumn{6}{|c|}{$1970-1979$} \\
\hline Full & -0.278 & 0.747 & 0.520 & 0.194 & 0.204 \\
\hline IDC & 0.257 & 0.795 & 0.763 & 0.216 & 0.390 \\
\hline LDC & -0.424 & 0.735 & 0.457 & 0.188 & 0.156 \\
\hline EMG & -0.547 & 0.709 & 0.405 & 0.202 & 0.084 \\
\hline \multicolumn{6}{|c|}{$1980-1989$} \\
\hline Full & -0.296 & 0.758 & 0.458 & 0.212 & 0.196 \\
\hline IDC & 0.804 & 0.929 & 0.852 & 0.400 & 0.490 \\
\hline LDC & -0.570 & 0.716 & 0.362 & 0.166 & 0.123 \\
\hline EMG & -0.571 & 0.690 & 0.290 & 0.187 & 0.142 \\
\hline \multicolumn{6}{|c|}{$1990-2000$} \\
\hline Full & 0.485 & 0.862 & 0.564 & 0.524 & 0.376 \\
\hline IDC & 2.152 & 1.000 & 0.963 & 0.929 & 0.883 \\
\hline LDC & 0.069 & 0.827 & 0.463 & 0.422 & 0.247 \\
\hline EMG & 0.274 & 0.833 & 0.490 & 0.437 & 0.379 \\
\hline \multicolumn{6}{|c|}{$1995-2000$} \\
\hline Full & 0.679 & 0.895 & 0.546 & 0.474 & 0.452 \\
\hline IDC & 2.407 & 1.000 & 0.962 & 0.902 & 0.992 \\
\hline LDC & 0.241 & 0.868 & 0.440 & 0.364 & 0.314 \\
\hline EMG & 0.555 & 0.882 & 0.516 & 0.419 & 0.473 \\
\hline
\end{tabular}

Notes: KAOPEN is an index for the openness in capital account transactions and is the first standardized principal component of SHAREk3, $k 1, k 2$, and $k 4 . k_{1}$ indicates the presence of multiple exchange rates; $k_{2}$ indicates restrictions on current account transactions; $k_{3}$ indicates restrictions on capital account transactions; and $k_{4}$ indicates the requirement of the surrender of export proceeds. In order to focus on the effect of financial openness - rather than controls - we reverse the values of these binary variables, such that the variables are equal to one when the capital account restrictions are non-existent. The first eigenvector for KAOPEN was found to be (SHAREk $k_{3}, k_{1}, k_{2}$, $\left.k_{4}\right)^{\prime}=(0.573,0.273,0.521,0.571)^{\prime}$, indicating that the variability of $K A O P E N$ is not merely driven by the SHAREk 3 series. The average of KAOPEN across countries over the full time period is zero by construction. See Appendix 2 for more details. 
Table 3: Summary Statistics on Legall variables

\begin{tabular}{c|c|c|c|c|c}
\hline & & Mean & Std. Dev. & Min & Max \\
\hline \hline \multirow{4}{*}{ Legal1 } & Total & 0.00 & 1.63 & -2.93 & 3.06 \\
& IDC & 2.41 & 0.75 & 0.68 & 3.06 \\
& LDC & -0.74 & 0.98 & -2.93 & 1.76 \\
& EMG & -0.28 & 0.98 & -1.98 & 1.76 \\
\hline \multirow{5}{*}{ Corrupt } & Total & 58.40 & 21.93 & 15.18 & 100.00 \\
& IDC & 88.27 & 10.94 & 62.80 & 100.00 \\
& LDC & 49.27 & 15.28 & 15.18 & 87.20 \\
& EMG & 54.73 & 15.02 & 26.79 & 87.20 \\
\hline \multirow{5}{*}{ LAO } & Total & 60.87 & 22.82 & 22.62 & 100.00 \\
& IDC & 93.63 & 8.83 & 68.75 & 100.00 \\
& LDC & 50.85 & 15.00 & 22.62 & 87.80 \\
& EMG & 55.76 & 18.01 & 22.62 & 87.80 \\
\hline & Total & 58.86 & 24.73 & 16.67 & 100.00 \\
& IDC & 92.26 & 13.77 & 57.89 & 100.00 \\
& LDC & 48.66 & 17.14 & 16.67 & 93.45 \\
& EMG & 56.44 & 14.26 & 29.32 & 93.45 \\
\hline
\end{tabular}

Notes: $L E G A L 1$ is the first principal component of Corrupt, LAO, $B Q$, indicating the general level of legal/institutional development. Corrupt, $L A O$, and $B Q$ measure the level of corruption, law and order, and the quality of the bureaucratic system, respectively. All of these data series included in LEGALI are obtained from the ICRG database. In these indexes, higher values indicate better conditions. The data series are available for the period of 1984 through 1997, but are included as the period-average in order to maintain

comparability with the $L E G A L 2$ variables. The first eigenvector for Legall was found to be (Corrupt, $L A O, B Q)^{\prime}=(0.574,0.580$,

0.578 )', indicating that the variability of $L E G A L 1$ is not merely driven by any particular series.
Table 4: Summary Statistics on Legal2 variables

\begin{tabular}{c|c|c|c|c|c}
\hline & & Mean & Std. Dev. & Min & Max \\
\hline \hline \multirow{3}{*}{ Legal2 } & Total & 0.00 & 1.31 & -2.71 & 1.89 \\
& IDC & 0.70 & 0.86 & -1.59 & 1.89 \\
& LDC/EMG & -0.77 & 1.31 & -2.71 & 1.77 \\
\hline \multirow{2}{*}{ Creditor } & Total & 2.30 & 1.38 & 0.00 & 4.00 \\
protection & IDC & 1.81 & 0.98 & 0.00 & 4.00 \\
& LDC/EMG & 2.72 & 1.54 & 0.00 & 4.00 \\
\hline \multirow{2}{*}{ Contract } & Total & 7.52 & 1.85 & 4.38 & 9.99 \\
Enforcement & IDC & 9.24 & 0.83 & 6.73 & 9.99 \\
& LDC/EMG & 6.18 & 1.19 & 4.38 & 9.18 \\
\hline \multirow{2}{*}{ Shareholder } & Total & 2.45 & 1.28 & 0.00 & 5.00 \\
Protection & IDC & 2.19 & 1.29 & 0.00 & 4.00 \\
& LDC/EMG & 2.65 & 1.26 & 1.00 & 5.00 \\
\hline \multirow{2}{*}{ Accounting } & Total & 6.08 & 1.36 & 2.40 & 8.30 \\
Standards & IDC & 6.62 & 1.04 & 3.60 & 8.30 \\
& LDC/EMG & 5.55 & 1.44 & 2.40 & 7.80 \\
\hline \multirow{2}{*}{ ID } & DD
\end{tabular}

Notes: $L E G A L 2$ is the first standardized principal component of CREDITOR, ENFORCE, SHRIGHTS, and ACCOUNT, and depicts the overall development of the legal system governing financial transactions. CREDITOR refers to the level of creditor protection, while ENFORCE is an index of the effectiveness of the legal system in enforcing contracts. SHRIGHTS is a measure of shareholder protection, and ACCOUNT is an index of the comprehensiveness of company reports. This group of legal variables pertain specifically to financial transactions, and are obtained from LLSV (1998). The first eigenvector for Legal2 was found to be (Creditor, Enforce, Shrights, Account $)^{\prime}=(0.206,0.670,0.095,0.707)^{\prime}$. 
Table 5-1: Financial Development, Financial Openness, and Legal/Institutional Development

(LEGAL1: General Legal/Institutional Development)

FULL, LDC, and EMG: Five year panels, 1980-2000

\begin{tabular}{|c|c|c|c|c|c|c|c|c|c|c|c|c|c|}
\hline & & \multicolumn{4}{|c|}{ FULL } & \multicolumn{4}{|c|}{ LDC } & \multicolumn{4}{|c|}{ EMG } \\
\hline & $\begin{array}{c}\text { Pred } \\
\text { sign }\end{array}$ & $\begin{array}{c}\text { Private } \\
\text { Credit } \\
{[1]} \\
\end{array}$ & $\begin{array}{c}\text { Stock Mkt } \\
\text { Capital'n } \\
{[2]} \\
\end{array}$ & $\begin{array}{c}\text { Stock Mkt } \\
\text { Total Value } \\
{[3]}\end{array}$ & $\begin{array}{c}\text { Stock Mkt } \\
\text { Turnover } \\
{[4]}\end{array}$ & $\begin{array}{c}\text { Private } \\
\text { Credit } \\
{[5]}\end{array}$ & $\begin{array}{c}\text { Stock Mkt } \\
\text { Capital'n } \\
{[6]}\end{array}$ & $\begin{array}{c}\text { Stock Mkt } \\
\text { Total Value } \\
{[7]}\end{array}$ & $\begin{array}{c}\text { Stock Mkt } \\
\text { Turnover } \\
{[8]}\end{array}$ & $\begin{array}{c}\text { Private } \\
\text { Credit } \\
{[9]}\end{array}$ & $\begin{array}{c}\text { Stock Mkt } \\
\text { Capital'n } \\
{[10]}\end{array}$ & $\begin{array}{c}\text { Stock Mkt } \\
\text { Total Value } \\
{[11]}\end{array}$ & $\begin{array}{c}\text { Stock Mkt } \\
\text { Turnover } \\
{[12]}\end{array}$ \\
\hline \multicolumn{14}{|c|}{ Legal/Inst. Variable: LEGAL1 } \\
\hline Financial Openness [t-5] & $(+)$ & $\begin{array}{c}0.0027 \\
{[0.0011]^{* *}}\end{array}$ & $\begin{array}{l}-0.0009 \\
{[0.0041]}\end{array}$ & $\begin{array}{l}-0.0036 \\
{[0.0031]}\end{array}$ & $\begin{array}{l}-0.0041 \\
{[0.0097]}\end{array}$ & $\begin{array}{c}0.0004 \\
{[0.0013]}\end{array}$ & $\begin{array}{c}0.0050 \\
{[0.0078]}\end{array}$ & $\begin{array}{c}0.0070 \\
{[0.0042]^{*}}\end{array}$ & $\begin{array}{c}0.0096 \\
{[0.0123]}\end{array}$ & $\begin{array}{c}0.0028 \\
{[0.0024]}\end{array}$ & $\begin{array}{c}0.0097 \\
{[0.0070]}\end{array}$ & $\begin{array}{c}0.0081 \\
{[0.0044]^{*}}\end{array}$ & $\begin{array}{c}0.0013 \\
{[0.0179]}\end{array}$ \\
\hline LEVEL: LEGAL1 & $(+)$ & $\begin{array}{c}0.0014 \\
{[0.0010]}\end{array}$ & $\begin{array}{l}-0.0025 \\
{[0.0057]}\end{array}$ & $\begin{array}{c}-0.004 \\
{[0.0051]}\end{array}$ & $\begin{array}{l}-0.0047 \\
{[0.0127]}\end{array}$ & $\begin{array}{c}0.0011 \\
{[0.0014]}\end{array}$ & $\begin{array}{c}0.0126 \\
{[0.0081]}\end{array}$ & $\begin{array}{c}0.0091 \\
{[0.0053]^{*}}\end{array}$ & $\begin{array}{c}0.0048 \\
{[0.0186]}\end{array}$ & $\begin{array}{c}0.0077 \\
{[0.0032]^{* *}}\end{array}$ & $\begin{array}{c}0.0177 \\
{[0.0098]^{*}}\end{array}$ & $\begin{array}{c}0.0117 \\
{[0.0082]}\end{array}$ & $\begin{array}{c}0.0098 \\
{[0.0277]}\end{array}$ \\
\hline $\begin{array}{c}\text { INTERACTION: } L E G A L 1 \\
\text { x Fin. Open. [t-5] }\end{array}$ & $(+)$ & $\begin{array}{c}0.0005 \\
{[0.0005]}\end{array}$ & $\begin{array}{c}0.0035 \\
{[0.0019]^{*}}\end{array}$ & $\begin{array}{c}0.0037 \\
{[0.0015]^{* *}}\end{array}$ & $\begin{array}{c}0.0045 \\
{[0.0039]}\end{array}$ & $\begin{array}{l}-0.0009 \\
{[0.0010]}\end{array}$ & $\begin{array}{c}0.0037 \\
{[0.0043]}\end{array}$ & $\begin{array}{c}0.0103 \\
{[0.0035]^{* * *}}\end{array}$ & $\begin{array}{c}0.0213 \\
{[0.0109]^{*}}\end{array}$ & $\begin{array}{c}0.0024 \\
{[0.0025]}\end{array}$ & $\begin{array}{c}0.0072 \\
{[0.0042]^{*}}\end{array}$ & $\begin{array}{c}0.0118 \\
{[0.0033]^{* * *}}\end{array}$ & $\begin{array}{c}0.019 \\
{[0.0102]^{*}}\end{array}$ \\
\hline Financial Deepening [t-5] & $(-)$ & $\begin{array}{c}-0.017 \\
{[0.0085]^{* *}}\end{array}$ & $\begin{array}{l}-0.0335 \\
{[0.0307]}\end{array}$ & $\begin{array}{c}0.1445 \\
{[0.0936]}\end{array}$ & $\begin{array}{l}-0.0358 \\
{[0.0344]}\end{array}$ & $\begin{array}{c}0.0001 \\
{[0.0119]}\end{array}$ & $\begin{array}{l}-0.0493 \\
{[0.0380]}\end{array}$ & $\begin{array}{c}0.0795 \\
{[0.1187]}\end{array}$ & $\begin{array}{l}-0.0033 \\
{[0.0536]}\end{array}$ & $\begin{array}{l}-0.0117 \\
{[0.0139]}\end{array}$ & $\begin{array}{l}-0.0349 \\
{[0.0382]}\end{array}$ & $\begin{array}{c}0.0926 \\
{[0.1208]}\end{array}$ & $\begin{array}{c}0.0014 \\
{[0.0683]}\end{array}$ \\
\hline $\begin{array}{l}\text { Per Capita } \\
\quad \text { Income [t-5] }\end{array}$ & $(+)$ & $\begin{array}{c}0.0037 \\
{[0.0015]^{* *}}\end{array}$ & $\begin{array}{c}0.0164 \\
{[0.0106]}\end{array}$ & $\begin{array}{c}0.016 \\
{[0.0104]}\end{array}$ & $\begin{array}{c}0.0053 \\
{[0.0227]}\end{array}$ & $\begin{array}{c}0.0031 \\
{[0.0015]^{* *}}\end{array}$ & $\begin{array}{c}0.0187 \\
{[0.0126]}\end{array}$ & $\begin{array}{c}0.0128 \\
{[0.0123]}\end{array}$ & $\begin{array}{l}-0.0023 \\
{[0.0273]}\end{array}$ & $\begin{array}{l}-0.0031 \\
{[0.0030]}\end{array}$ & $\begin{array}{c}0.0018 \\
{[0.0125]}\end{array}$ & $\begin{array}{c}0.0049 \\
{[0.0159]}\end{array}$ & $\begin{array}{l}-0.0134 \\
{[0.0448]}\end{array}$ \\
\hline Inflation [t-5] & $(-)$ & $\begin{array}{c}-0.0112 \\
{[0.0074]}\end{array}$ & $\begin{array}{c}-0.0548 \\
{[0.0208]^{* * *}}\end{array}$ & $\begin{array}{l}-0.0318 \\
{[0.0266]}\end{array}$ & $\begin{array}{l}-0.0561 \\
{[0.0919]}\end{array}$ & $\begin{array}{l}-0.0047 \\
{[0.0074]}\end{array}$ & $\begin{array}{l}-0.0497 \\
{[0.0303]}\end{array}$ & $\begin{array}{l}-0.0221 \\
{[0.0317]}\end{array}$ & $\begin{array}{l}-0.0815 \\
{[0.1166]}\end{array}$ & $\begin{array}{c}-0.0248 \\
{[0.0104]^{* *}}\end{array}$ & $\begin{array}{l}-0.0334 \\
{[0.0293]}\end{array}$ & $\begin{array}{l}-0.0164 \\
{[0.0414]}\end{array}$ & $\begin{array}{l}-0.1095 \\
{[0.1863]}\end{array}$ \\
\hline $\begin{array}{l}\text { Trade } \\
\qquad \text { Openness [t-5] }\end{array}$ & $(+)$ & $\begin{array}{c}0.0000 \\
{[0.0000]^{*}}\end{array}$ & $\begin{array}{c}0.0002 \\
{[0.0001]^{* *}}\end{array}$ & $\begin{array}{l}-0.0001 \\
{[0.0001]}\end{array}$ & $\begin{array}{c}-0.0003 \\
{[0.0001]^{* *}}\end{array}$ & $\begin{array}{c}0.0000 \\
{[0.0000]}\end{array}$ & $\begin{array}{c}0.0001 \\
{[0.0001]}\end{array}$ & $\begin{array}{c}-0.0003 \\
{[0.0002]^{*}}\end{array}$ & $\begin{array}{c}-0.0006 \\
{[0.0003]^{*}}\end{array}$ & $\begin{array}{c}0.0000 \\
{[0.0001]}\end{array}$ & $\begin{array}{c}0.0000 \\
{[0.0001]}\end{array}$ & $\begin{array}{c}-0.0003 \\
{[0.0002] * *}\end{array}$ & $\begin{array}{c}-0.0006 \\
{[0.0003]^{* *}}\end{array}$ \\
\hline $\mathrm{N}$ & & 408 & 175 & 206 & 172 & 289 & 101 & 115 & 98 & 138 & 87 & 97 & 85 \\
\hline Adj. R-sq. & & 0.15 & 0.11 & 0.28 & 0.03 & 0.09 & 0.2 & 0.16 & -0.01 & 0.16 & 0.19 & 0.18 & 0.01 \\
\hline
\end{tabular}

Notes: Point estimates from OLS, heteroskedasticity robust standard errors in parentheses. Dependent variable is the average annual growth rate over a five year period. Financial openness is measured by the Chinn-Ito index (KAOPEN). Regressions include fixed time effects (estimates not reported). Observations of inflation rates in excess of $100 \%$ are dropped from the sample. $(*)[* *]\{* * *\}$ indicates marginal significance at the $(10 \%)[5 \%]\{1 \%\}$ level. 
Table 5-2: Financial Development, Financial Openness, and Legal/Institutional Development

(Components of LEGAL1: Corruption, Law and Order, and Bureaucracy Quality)

FULL, LDC, and EMG: Five year panels, 1980-2000

\begin{tabular}{|c|c|c|c|c|c|c|c|c|c|c|c|c|c|}
\hline & & \multicolumn{4}{|c|}{ FULL } & \multicolumn{4}{|c|}{ LDC } & \multicolumn{4}{|c|}{ EMG } \\
\hline & $\begin{array}{l}\text { Pred } \\
\text { sign }\end{array}$ & $\begin{array}{c}\text { Private } \\
\text { Credit } \\
{[1]}\end{array}$ & $\begin{array}{c}\text { Stock Mkt } \\
\text { Capital'n } \\
{[2]} \\
\end{array}$ & $\begin{array}{c}\text { Stock Mkt } \\
\text { Total Val. } \\
{[3]} \\
\end{array}$ & $\begin{array}{c}\text { Stock Mkt } \\
\text { Turnover } \\
{[4]} \\
\end{array}$ & $\begin{array}{c}\text { Private } \\
\text { Credit } \\
\text { [5] }\end{array}$ & $\begin{array}{c}\text { Stock Mkt } \\
\text { Capital'n } \\
{[6]} \\
\end{array}$ & $\begin{array}{c}\text { Stock Mkt } \\
\text { Total Val. } \\
{[7]}\end{array}$ & $\begin{array}{c}\text { Stock Mkt } \\
\text { Turnover } \\
{[8]} \\
\end{array}$ & $\begin{array}{c}\text { Private } \\
\text { Credit } \\
{[9]}\end{array}$ & $\begin{array}{c}\text { Stock Mkt } \\
\text { Capital'n } \\
{[10]} \\
\end{array}$ & $\begin{array}{c}\text { Stock Mkt } \\
\text { Total Val. } \\
{[11]}\end{array}$ & $\begin{array}{c}\text { Stock Mkt } \\
\text { Turnover } \\
{[12]} \\
\end{array}$ \\
\hline \multicolumn{14}{|c|}{ Legal/Inst. Variable: Corrupt (Corruption) } \\
\hline Financial Openness [t-5] & $(+)$ & $\begin{array}{c}-0.0009 \\
{[0.0027]}\end{array}$ & $\begin{array}{l}-0.0129 \\
{[0.0099]}\end{array}$ & $\begin{array}{c}-0.0195 \\
{[0.0071]^{* * *}}\end{array}$ & $\begin{array}{l}-0.0309 \\
{[0.0261]}\end{array}$ & $\begin{array}{c}0.0009 \\
{[0.0038]}\end{array}$ & $\begin{array}{c}-0.0112 \\
{[0.0134]}\end{array}$ & $\begin{array}{c}-0.0313 \\
{[0.0110]^{* * *}}\end{array}$ & $\begin{array}{l}-0.0610 \\
{[0.0409]}\end{array}$ & $\begin{array}{c}-0.006 \\
{[0.0091]}\end{array}$ & $\begin{array}{c}-0.0193 \\
{[0.0146]}\end{array}$ & $\begin{array}{c}-0.0362 \\
{[0.0124]^{* * *}}\end{array}$ & $\begin{array}{l}-0.0634 \\
{[0.0460]}\end{array}$ \\
\hline LEVEL: CORRUPT & $(+)$ & $\begin{array}{c}0.0001 \\
{[0.0001]}\end{array}$ & $\begin{array}{c}0.0003 \\
{[0.0005]}\end{array}$ & $\begin{array}{c}-0.0002 \\
{[0.0003]}\end{array}$ & $\begin{array}{c}-0.0012 \\
{[0.0008]}\end{array}$ & $\begin{array}{c}0.0000 \\
{[0.0001]}\end{array}$ & $\begin{array}{c}0.0014 \\
{[0.0007]^{* *}}\end{array}$ & $\begin{array}{c}0.0004 \\
{[0.0004]}\end{array}$ & $\begin{array}{c}-0.0012 \\
{[0.0011]}\end{array}$ & $\begin{array}{c}0.0004 \\
{[0.0002]^{*}}\end{array}$ & $\begin{array}{c}0.0016 \\
{[0.0007]^{* *}}\end{array}$ & $\begin{array}{c}0.0005 \\
{[0.0006]}\end{array}$ & $\begin{array}{c}-0.0012 \\
{[0.0016]}\end{array}$ \\
\hline $\begin{array}{l}\text { INTERACTION: } \\
\text { Corrupt x Fin. Opn. [t-5] }\end{array}$ & $(+)$ & $\begin{array}{c}0.0001 \\
{[0.0000]}\end{array}$ & $\begin{array}{c}0.0002 \\
{[0.0001]}\end{array}$ & $\begin{array}{c}0.0003 \\
{[0.0001]^{* *}}\end{array}$ & $\begin{array}{c}0.0004 \\
{[0.0003]}\end{array}$ & $\begin{array}{c}0.0000 \\
{[0.0001]}\end{array}$ & $\begin{array}{c}0.0003 \\
{[0.0003]}\end{array}$ & $\begin{array}{c}0.0006 \\
{[0.0002]^{* * *}}\end{array}$ & $\begin{array}{c}0.001 \\
{[0.0006]^{*}}\end{array}$ & $\begin{array}{c}0.0001 \\
{[0.0002]}\end{array}$ & $\begin{array}{c}0.0005 \\
{[0.0003]^{*}}\end{array}$ & $\begin{array}{c}0.0007 \\
{[0.0002]^{* * *}}\end{array}$ & $\begin{array}{c}0.0009 \\
{[0.0006]}\end{array}$ \\
\hline $\mathrm{N}$ & & 408 & 175 & 206 & 172 & 289 & 101 & 115 & 98 & 138 & 87 & 97 & 85 \\
\hline Adj. R-sq. & & 0.15 & 0.12 & 0.28 & 0.03 & 0.09 & 0.23 & 0.16 & -0.01 & 0.14 & 0.24 & 0.18 & 0.00 \\
\hline \multicolumn{14}{|c|}{ Legal/Inst. Variable: $L A O$ (Law and order) } \\
\hline Financial Openness [t-5] & $(+)$ & $\begin{array}{c}-0.0003 \\
{[0.0025]}\end{array}$ & $\begin{array}{c}-0.0172 \\
{[0.0097]^{*}}\end{array}$ & $\begin{array}{c}-0.0172 \\
{[0.0083]^{* *}}\end{array}$ & $\begin{array}{l}-0.0204 \\
{[0.0229]}\end{array}$ & $\begin{array}{c}0.004 \\
{[0.0029]}\end{array}$ & $\begin{array}{c}-0.0217 \\
{[0.0125]^{*}}\end{array}$ & $\begin{array}{c}-0.0218 \\
{[0.0119]^{*}}\end{array}$ & $\begin{array}{c}-0.0627 \\
{[0.0443]}\end{array}$ & $\begin{array}{l}-0.0078 \\
{[0.0076]}\end{array}$ & $\begin{array}{c}-0.0278 \\
{[0.0107]^{* *}}\end{array}$ & $\begin{array}{c}-0.0239 \\
{[0.0105]^{* *}}\end{array}$ & $\begin{array}{l}-0.0536 \\
{[0.0385]}\end{array}$ \\
\hline LEVEL: $L A O$ & $(+)$ & $\begin{array}{c}0.0001 \\
{[0.0001]}\end{array}$ & $\begin{array}{l}-0.0003 \\
{[0.0004]}\end{array}$ & $\begin{array}{l}-0.0001 \\
{[0.0003]}\end{array}$ & $\begin{array}{c}0.0001 \\
{[0.0007]}\end{array}$ & $\begin{array}{c}0.0001 \\
{[0.0001]}\end{array}$ & $\begin{array}{c}0.0004 \\
{[0.0004]}\end{array}$ & $\begin{array}{c}0.0003 \\
{[0.0003]}\end{array}$ & $\begin{array}{c}0.0005 \\
{[0.0009]}\end{array}$ & $\begin{array}{c}0.0004 \\
{[0.0002]^{* *}}\end{array}$ & $\begin{array}{c}0.0005 \\
{[0.0004]}\end{array}$ & $\begin{array}{c}0.0003 \\
{[0.0004]}\end{array}$ & $\begin{array}{c}0.0008 \\
{[0.0011]}\end{array}$ \\
\hline $\begin{array}{l}\text { INTERACTION: } \\
L A O \text { x Fin. Opn. [t-5] }\end{array}$ & $(+)$ & $\begin{array}{c}0.0000 \\
{[0.0000]}\end{array}$ & $\begin{array}{c}0.0003 \\
{[0.0001]^{* *}}\end{array}$ & $\begin{array}{c}0.0002 \\
{[0.0001]^{*}}\end{array}$ & $\begin{array}{c}0.0003 \\
{[0.0003]}\end{array}$ & $\begin{array}{l}-0.0001 \\
{[0.0001]}\end{array}$ & $\begin{array}{c}0.0004 \\
{[0.0003]}\end{array}$ & $\begin{array}{c}0.0004 \\
{[0.0002]^{*}}\end{array}$ & $\begin{array}{c}0.0011 \\
{[0.0007]}\end{array}$ & $\begin{array}{c}0.0001 \\
{[0.0001]}\end{array}$ & $\begin{array}{c}0.0006 \\
{[0.0002]^{* *}}\end{array}$ & $\begin{array}{c}0.0004 \\
{[0.0002]^{* *}}\end{array}$ & $\begin{array}{c}0.0008 \\
{[0.0005]}\end{array}$ \\
\hline $\mathrm{N}$ & & 408 & 175 & 206 & 172 & 289 & 101 & 115 & 98 & 138 & 87 & 97 & 85 \\
\hline Adj. R-sq. & & 0.15 & 0.12 & 0.28 & 0.03 & 0.09 & 0.2 & 0.12 & -0.02 & 0.14 & 0.19 & 0.12 & -0.01 \\
\hline \multicolumn{14}{|c|}{ Legal/Inst. Variable: $B Q$ (Bureaucracy Quality) } \\
\hline Financial Openness [t-5] & $(+)$ & $\begin{array}{c}0.002 \\
{[0.0024]}\end{array}$ & $\begin{array}{l}-0.0070 \\
{[0.0102]}\end{array}$ & $\begin{array}{c}-0.0119 \\
{[0.0070]^{*}}\end{array}$ & $\begin{array}{l}-0.0101 \\
{[0.0205]}\end{array}$ & $\begin{array}{c}0.0048 \\
{[0.0032]}\end{array}$ & $\begin{array}{c}0.0057 \\
{[0.0107]}\end{array}$ & $\begin{array}{c}-0.0268 \\
{[0.0129]^{* *}}\end{array}$ & $\begin{array}{c}-0.0562 \\
{[0.0333]^{*}}\end{array}$ & $\begin{array}{l}-0.0035 \\
{[0.0079]}\end{array}$ & $\begin{array}{c}0.009 \\
{[0.0136]}\end{array}$ & $\begin{array}{c}-0.0334 \\
{[0.0165]^{* *}}\end{array}$ & $\begin{array}{l}-0.0749 \\
{[0.0471]}\end{array}$ \\
\hline LEVEL: $B Q$ & $(+)$ & $\begin{array}{c}0.0001 \\
{[0.0001]^{*}}\end{array}$ & $\begin{array}{c}0.0000 \\
{[0.0004]}\end{array}$ & $\begin{array}{l}-0.0001 \\
{[0.0002]}\end{array}$ & $\begin{array}{c}0.0004 \\
{[0.0007]}\end{array}$ & $\begin{array}{c}0.0001 \\
{[0.0001]}\end{array}$ & $\begin{array}{c}0.0003 \\
{[0.0005]}\end{array}$ & $\begin{array}{c}0.0007 \\
{[0.0004]^{*}}\end{array}$ & $\begin{array}{c}0.0014 \\
{[0.0010]}\end{array}$ & $\begin{array}{c}0.0002 \\
{[0.0002]}\end{array}$ & $\begin{array}{c}0.0004 \\
{[0.0006]}\end{array}$ & $\begin{array}{c}0.0009 \\
{[0.0005]^{*}}\end{array}$ & $\begin{array}{c}0.0019 \\
{[0.0014]}\end{array}$ \\
\hline $\begin{array}{l}\text { INTERACTION: } \\
\quad B Q \times \text { Fin. Opn. [t-5] }\end{array}$ & $(+)$ & $\begin{array}{c}0.0000 \\
{[0.0000]}\end{array}$ & $\begin{array}{c}0.0001 \\
{[0.0001]}\end{array}$ & $\begin{array}{c}0.0002 \\
{[0.0001]}\end{array}$ & $\begin{array}{c}0.0001 \\
{[0.0002]}\end{array}$ & $\begin{array}{c}-0.0001 \\
{[0.0001]}\end{array}$ & $\begin{array}{c}-0.0001 \\
{[0.0002]}\end{array}$ & $\begin{array}{c}0.0006 \\
{[0.0003]^{* *}}\end{array}$ & $\begin{array}{c}0.0011 \\
{[0.0006]^{* *}}\end{array}$ & $\begin{array}{c}0.0001 \\
{[0.0001]}\end{array}$ & $\begin{array}{c}-0.0001 \\
{[0.0003]}\end{array}$ & $\begin{array}{c}0.0007 \\
{[0.0003]^{* *}}\end{array}$ & $\begin{array}{c}0.0014 \\
{[0.0007]^{*}}\end{array}$ \\
\hline $\mathrm{N}$ & & 408 & 175 & 206 & 172 & 289 & 101 & 115 & 98 & 138 & 87 & 97 & 85 \\
\hline Adj. R-sq. & & 0.15 & 0.10 & 0.27 & 0.02 & 0.10 & 0.18 & 0.17 & 0.00 & 0.11 & 0.15 & 0.17 & 0.02 \\
\hline
\end{tabular}

Notes: Point estimates from OLS, heteroskedasticity robust standard errors in parentheses. Dependent variable is the average annual growth rate over a five year period.

Financial openness is measured by the Chinn-Ito index $(K A O P E N)$. Regressions include fixed time effects (estimates not reported). Observations of inflation rates in excess of $100 \%$ are dropped from the sample. $(*)[* *]\{* *\}$ indicates marginal significance at the $(10 \%)[5 \%]\{1 \%\}$ level. 
Table 5-3: Financial Development, Financial Openness, and Legal/Institutional Development (LEGAL2: Legal Development pertaining to Financial Transactions)

FULL, LDC, and EMG: Five year panels, 1980-2000

\begin{tabular}{|c|c|c|c|c|c|c|c|c|c|}
\hline & & \multicolumn{4}{|c|}{ FULL } & \multicolumn{4}{|c|}{ LDC/EMG } \\
\hline & $\begin{array}{c}\text { Pred } \\
\text { sign } \\
\end{array}$ & $\begin{array}{c}\text { Private } \\
\text { Credit } \\
{[1]}\end{array}$ & $\begin{array}{c}\text { Stock Mkt } \\
\text { Capital'n } \\
{[2]} \\
\end{array}$ & $\begin{array}{c}\text { Stock Mkt } \\
\text { Total Val. } \\
{[3]} \\
\end{array}$ & $\begin{array}{c}\text { Stock Mkt } \\
\text { Turnover } \\
{[4]} \\
\end{array}$ & $\begin{array}{c}\text { Private } \\
\text { Credit } \\
{[5]}\end{array}$ & $\begin{array}{c}\text { Stock Mkt } \\
\text { Capital'n } \\
{[6]} \\
\end{array}$ & $\begin{array}{c}\text { Stock Mkt } \\
\text { Total Val. } \\
{[7]} \\
\end{array}$ & $\begin{array}{c}\text { Stock Mkt } \\
\text { Turnover } \\
{[8]} \\
\end{array}$ \\
\hline \multicolumn{10}{|c|}{ Legal/Inst. Variable: LEGAL2 } \\
\hline Financial Openness [t-5] & $(+)$ & $\begin{array}{c}0.0036 \\
{[0.0016]^{* *}}\end{array}$ & $\begin{array}{c}0.0020 \\
{[0.0053]}\end{array}$ & $\begin{array}{c}0.0018 \\
{[0.0037]}\end{array}$ & $\begin{array}{c}0.0053 \\
{[0.0092]}\end{array}$ & $\begin{array}{c}0.0000 \\
{[0.0020]}\end{array}$ & $\begin{array}{c}0.0072 \\
{[0.0136]}\end{array}$ & $\begin{array}{c}0.0111 \\
{[0.0062]^{*}}\end{array}$ & $\begin{array}{c}0.0195 \\
{[0.0187]}\end{array}$ \\
\hline LEVEL: LEGAL2 & $(+)$ & $\begin{array}{c}-0.0001 \\
{[0.0022]}\end{array}$ & $\begin{array}{c}0.0086 \\
{[0.0066]}\end{array}$ & $\begin{array}{c}0.0027 \\
{[0.0057]}\end{array}$ & $\begin{array}{c}0.0126 \\
{[0.0177]}\end{array}$ & $\begin{array}{c}0.001 \\
{[0.0033]}\end{array}$ & $\begin{array}{c}0.0175 \\
{[0.0115]}\end{array}$ & $\begin{array}{c}0.0141 \\
{[0.0087]^{*}}\end{array}$ & $\begin{array}{c}0.0288 \\
{[0.0261]}\end{array}$ \\
\hline $\begin{array}{l}\text { INTERACTION: } \\
\text { LEGAL2 x Fin. Open. [t-5] }\end{array}$ & $(+)$ & $\begin{array}{c}0.0000 \\
{[0.0013]}\end{array}$ & $\begin{array}{c}0.0055 \\
{[0.0030]^{*}}\end{array}$ & $\begin{array}{c}0.0036 \\
{[0.0031]}\end{array}$ & $\begin{array}{l}-0.0028 \\
{[0.0049]}\end{array}$ & $\begin{array}{c}-0.0013 \\
{[0.0017]}\end{array}$ & $\begin{array}{c}0.0029 \\
{[0.0070]}\end{array}$ & $\begin{array}{c}0.0077 \\
{[0.0041]^{*}}\end{array}$ & $\begin{array}{c}0.0113 \\
{[0.0110]}\end{array}$ \\
\hline Financial Deepening [t-5] & $(-)$ & $\begin{array}{c}-0.0275 \\
{[0.0109]^{* *}}\end{array}$ & $\begin{array}{l}-0.0465 \\
{[0.0367]}\end{array}$ & $\begin{array}{c}0.0997 \\
{[0.1083]}\end{array}$ & $\begin{array}{l}-0.0637 \\
{[0.0434]}\end{array}$ & $\begin{array}{l}-0.0106 \\
{[0.0173]}\end{array}$ & $\begin{array}{l}-0.0532 \\
{[0.0454]}\end{array}$ & $\begin{array}{c}0.0212 \\
{[0.1442]}\end{array}$ & $\begin{array}{l}-0.0467 \\
{[0.0684]}\end{array}$ \\
\hline Per Capita Income [t-5] & $(+)$ & $\begin{array}{c}0.0025 \\
{[0.0026]}\end{array}$ & $\begin{array}{c}0.0004 \\
{[0.0097]}\end{array}$ & $\begin{array}{c}0.0047 \\
{[0.0084]}\end{array}$ & $\begin{array}{l}-0.0125 \\
{[0.0244]}\end{array}$ & $\begin{array}{c}0.0034 \\
{[0.0033]}\end{array}$ & $\begin{array}{c}0.0161 \\
{[0.0112]}\end{array}$ & $\begin{array}{c}0.012 \\
{[0.0112]}\end{array}$ & $\begin{array}{l}-0.0039 \\
{[0.0314]}\end{array}$ \\
\hline Inflation [t-5] & $(-)$ & $\begin{array}{c}-0.0237 \\
{[0.0140]^{*}}\end{array}$ & $\begin{array}{c}-0.0423 \\
{[0.0262]}\end{array}$ & $\begin{array}{c}-0.0203 \\
{[0.0345]}\end{array}$ & $\begin{array}{c}0.005 \\
{[0.1032]}\end{array}$ & $\begin{array}{c}-0.0206 \\
{[0.0149]}\end{array}$ & $\begin{array}{c}-0.0404 \\
{[0.0305]}\end{array}$ & $\begin{array}{c}-0.0016 \\
{[0.0381]}\end{array}$ & $\begin{array}{c}0.0108 \\
{[0.1350]}\end{array}$ \\
\hline Trade Openness [t-5] & $(+)$ & $\begin{array}{c}0.0000 \\
{[0.0000]}\end{array}$ & $\begin{array}{c}0.0002 \\
{[0.0001]}\end{array}$ & $\begin{array}{c}-0.0001 \\
{[0.0001]}\end{array}$ & $\begin{array}{c}-0.0002 \\
{[0.0001]^{*}}\end{array}$ & $\begin{array}{c}0.0000 \\
{[0.0000]}\end{array}$ & $\begin{array}{c}0.0001 \\
{[0.0003]}\end{array}$ & $\begin{array}{c}-0.0003 \\
{[0.0002]}\end{array}$ & $\begin{array}{l}-0.0007 \\
{[0.0005]}\end{array}$ \\
\hline $\mathrm{N}$ & & 188 & 124 & 148 & 123 & 93 & 60 & 68 & 59 \\
\hline Adj. R-sq. & & 0.11 & 0.10 & 0.29 & 0.05 & 0.17 & 0.14 & 0.12 & -0.05 \\
\hline
\end{tabular}

Notes: Point estimates from OLS, heteroskedasticity robust standard errors in parentheses. Dependent variable is the average annual growth rate over a five year period. Financial openness is measured by the Chinn-Ito index (KAOPEN). Regressions include fixed time effects (estimates not reported). Observations of inflation rates in excess of $100 \%$ are dropped from the sample. $(*)[* *]\{* *\}$ indicates marginal significance at the $(10 \%)[5 \%]\{1 \%\}$ level. Due to the data availability of the LLSV variables, there is only one subsample for non-industrialized countries, which we call LDC/EMG. 
Table 5-4: Financial Development, Financial Openness, and Legal/Institutional Development (Creditor Protection, Contract Enforcement, Shareholder Protection, and Accounting Standards) FULL, LDC, and EMG: Five year panels, 1980-2000

\begin{tabular}{|c|c|c|c|c|c|c|c|c|c|}
\hline & & \multicolumn{4}{|c|}{ FULL } & \multicolumn{4}{|c|}{ LDC/EMG } \\
\hline & $\begin{array}{c}\text { Pred } \\
\text { sign }\end{array}$ & $\begin{array}{c}\text { Private } \\
\text { Credit } \\
{[1]}\end{array}$ & $\begin{array}{c}\text { Stock Mkt } \\
\text { Capital'n } \\
{[2]}\end{array}$ & $\begin{array}{c}\text { Stock Mkt } \\
\text { Total Val. } \\
\text { [3] }\end{array}$ & $\begin{array}{c}\text { Stock Mkt } \\
\text { Turnover } \\
{[4]}\end{array}$ & $\begin{array}{c}\text { Private } \\
\text { Credit } \\
\text { [5] }\end{array}$ & $\begin{array}{c}\text { Stock Mkt } \\
\text { Capital'n } \\
{[6]}\end{array}$ & $\begin{array}{c}\text { Stock Mkt } \\
\text { Total Val. } \\
\text { [7] }\end{array}$ & $\begin{array}{c}\text { Stock Mkt } \\
\text { Turnover } \\
{[8]}\end{array}$ \\
\hline \multicolumn{10}{|c|}{ Legal/Inst. Variable: CREDITOR (Creditor Protection) } \\
\hline $\begin{array}{l}\text { Financial } \\
\text { Openness [t-5] }\end{array}$ & $(+)$ & $\begin{array}{c}0.0003 \\
{[0.0022]}\end{array}$ & $\begin{array}{c}0.0031 \\
{[0.0060]}\end{array}$ & $\begin{array}{c}0.0036 \\
{[0.0055]}\end{array}$ & $\begin{array}{c}0.0032 \\
{[0.0105]}\end{array}$ & $\begin{array}{c}0.0011 \\
{[0.0038]}\end{array}$ & $\begin{array}{l}-0.0013 \\
{[0.0050]}\end{array}$ & $\begin{array}{c}-0.0021 \\
{[0.0049]}\end{array}$ & $\begin{array}{c}-0.0058 \\
{[0.0205]}\end{array}$ \\
\hline LEVEL: CREDITOR & $(+)$ & $\begin{array}{c}0.0029 \\
{[0.0016]^{*}}\end{array}$ & $\begin{array}{l}-0.0020 \\
{[0.0038]}\end{array}$ & $\begin{array}{c}0.0012 \\
{[0.0035]}\end{array}$ & $\begin{array}{c}0.0169 \\
{[0.0089]^{*}}\end{array}$ & $\begin{array}{c}0.0030 \\
{[0.0018]^{*}}\end{array}$ & $\begin{array}{c}0.0027 \\
{[0.0035]}\end{array}$ & $\begin{array}{c}0.009 \\
{[0.0045]^{*}}\end{array}$ & $\begin{array}{c}0.0202 \\
{[0.0118]^{*}}\end{array}$ \\
\hline $\begin{array}{l}\text { INTERACTION: } \\
\text { CREDITOR x Fin. Opn. [t-5] }\end{array}$ & $(+)$ & $\begin{array}{c}0.0012 \\
{[0.0010]}\end{array}$ & $\begin{array}{c}-0.0003 \\
{[0.0023]}\end{array}$ & $\begin{array}{l}-0.0014 \\
{[0.0021]}\end{array}$ & $\begin{array}{c}-0.0018 \\
{[0.0034]}\end{array}$ & $\begin{array}{c}-0.0001 \\
{[0.0014]}\end{array}$ & $\begin{array}{c}0.0014 \\
{[0.0023]}\end{array}$ & $\begin{array}{c}0.0017 \\
{[0.0017]}\end{array}$ & $\begin{array}{c}0.0006 \\
{[0.0048]}\end{array}$ \\
\hline $\mathrm{N}$ & & 230 & 145 & 169 & 143 & 129 & 80 & 88 & 78 \\
\hline Adj. R-sq. & & 0.14 & 0.07 & 0.27 & 0.05 & 0.15 & 0.19 & 0.12 & -0.01 \\
\hline \multicolumn{10}{|c|}{ Legal/Inst. Variable: ENFORCE (Contract Enforcement) } \\
\hline $\begin{array}{l}\text { Financial } \\
\text { Openness [t-5] }\end{array}$ & $(+)$ & $\begin{array}{c}-0.0044 \\
{[0.0057]}\end{array}$ & $\begin{array}{c}-0.0342 \\
{[0.0160]^{* *}}\end{array}$ & $\begin{array}{c}-0.0211 \\
{[0.0125]^{*}}\end{array}$ & $\begin{array}{c}-0.0246 \\
{[0.0427]}\end{array}$ & $\begin{array}{c}-0.0080 \\
{[0.0131]}\end{array}$ & $\begin{array}{c}-0.0531 \\
{[0.0231]^{* *}}\end{array}$ & $\begin{array}{c}-0.0587 \\
{[0.0203]^{* * *}}\end{array}$ & $\begin{array}{c}-0.1509 \\
{[0.0974]}\end{array}$ \\
\hline LEVEL: ENFORCE & $(+)$ & $\begin{array}{c}0.0020 \\
{[0.0014]}\end{array}$ & $\begin{array}{c}-0.0068 \\
{[0.0070]}\end{array}$ & $\begin{array}{l}-0.0030 \\
{[0.0058]}\end{array}$ & $\begin{array}{c}0.0002 \\
{[0.0219]}\end{array}$ & $\begin{array}{c}0.0059 \\
{[0.0028]^{* *}}\end{array}$ & $\begin{array}{c}0.0037 \\
{[0.0080]}\end{array}$ & $\begin{array}{c}0.0097 \\
{[0.0079]}\end{array}$ & $\begin{array}{c}0.0077 \\
{[0.0342]}\end{array}$ \\
\hline $\begin{array}{l}\text { INTERACTION: } \\
\text { ENFORCE x Fin. Opn. [t-5] }\end{array}$ & $(+)$ & $\begin{array}{c}0.0009 \\
{[0.0007]}\end{array}$ & $\begin{array}{c}0.0051 \\
{[0.0021]^{* *}}\end{array}$ & $\begin{array}{c}0.003 \\
{[0.0017]^{*}}\end{array}$ & $\begin{array}{c}0.0034 \\
{[0.0054]}\end{array}$ & $\begin{array}{c}0.0015 \\
{[0.0021]}\end{array}$ & $\begin{array}{c}0.0093 \\
{[0.0042]^{* *}}\end{array}$ & $\begin{array}{c}0.0100 \\
{[0.0033]^{* * *}}\end{array}$ & $\begin{array}{c}0.0243 \\
{[0.0144]^{*}}\end{array}$ \\
\hline $\mathrm{N}$ & & 240 & 151 & 178 & 149 & 139 & 86 & 97 & 84 \\
\hline Adj. R-sq. & & 0.12 & 0.11 & 0.28 & 0.04 & 0.16 & 0.23 & 0.18 & 0.03 \\
\hline \multicolumn{10}{|c|}{ Legal/Inst. Variable: SHRIGHTS (Shareholder Protection) } \\
\hline $\begin{array}{l}\text { Financial } \\
\text { Openness [t-5] }\end{array}$ & $(+)$ & $\begin{array}{c}0.0031 \\
{[0.0022]}\end{array}$ & $\begin{array}{c}0.0039 \\
{[0.0047]}\end{array}$ & $\begin{array}{c}0.0021 \\
{[0.0042]}\end{array}$ & $\begin{array}{c}0.0237 \\
{[0.0148]}\end{array}$ & $\begin{array}{c}-0.0032 \\
{[0.0043]}\end{array}$ & $\begin{array}{c}0.0002 \\
{[0.0065]}\end{array}$ & $\begin{array}{c}0.0026 \\
{[0.0060]}\end{array}$ & $\begin{array}{c}0.0353 \\
{[0.0205]^{*}}\end{array}$ \\
\hline LEVEL: SHRIGHTS & $(+)$ & $\begin{array}{c}0.0007 \\
{[0.0010]}\end{array}$ & $\begin{array}{c}0.0105 \\
{[0.0043]^{* *}}\end{array}$ & $\begin{array}{c}0.0015 \\
{[0.0029]}\end{array}$ & $\begin{array}{c}0.0186 \\
{[0.0173]}\end{array}$ & $\begin{array}{c}0.0011 \\
{[0.0017]}\end{array}$ & $\begin{array}{c}0.0124 \\
{[0.0055]^{* *}}\end{array}$ & $\begin{array}{c}0.0033 \\
{[0.0050]}\end{array}$ & $\begin{array}{c}0.0174 \\
{[0.0220]}\end{array}$ \\
\hline $\begin{array}{l}\text { INTERACTION: } \\
\text { SHRIGHTS x Fin. Opn. [t-5] }\end{array}$ & $(+)$ & $\begin{array}{c}0.0000 \\
{[0.0007]}\end{array}$ & $\begin{array}{c}-0.0003 \\
{[0.0022]}\end{array}$ & $\begin{array}{c}-0.0004 \\
{[0.0017]}\end{array}$ & $\begin{array}{c}-0.0091 \\
{[0.0073]}\end{array}$ & $\begin{array}{c}0.0019 \\
{[0.0013]}\end{array}$ & $\begin{array}{c}0.0017 \\
{[0.0042]}\end{array}$ & $\begin{array}{c}0.0001 \\
{[0.0030]}\end{array}$ & $\begin{array}{c}-0.0155 \\
{[0.0099]}\end{array}$ \\
\hline $\mathrm{N}$ & & 234 & 147 & 174 & 145 & 133 & 82 & 93 & 80 \\
\hline Adj. R-sq. & & 0.11 & 0.11 & 0.27 & 0.07 & 0.13 & 0.21 & 0.11 & 0.03 \\
\hline \multicolumn{10}{|c|}{ Legal/Inst. Variable: ACCOUNT (Accounting Standards) } \\
\hline $\begin{array}{l}\text { Financial } \\
\text { Openness [t-5] }\end{array}$ & $(+)$ & $\begin{array}{c}0.0105 \\
{[0.0076]}\end{array}$ & $\begin{array}{c}-0.0298 \\
{[0.0184]}\end{array}$ & $\begin{array}{c}-0.0234 \\
{[0.0150]}\end{array}$ & $\begin{array}{c}-0.0046 \\
{[0.0227]}\end{array}$ & $\begin{array}{c}0.0137 \\
{[0.0111]}\end{array}$ & $\begin{array}{c}0.0112 \\
{[0.0208]}\end{array}$ & $\begin{array}{l}-0.0087 \\
{[0.0147]}\end{array}$ & $\begin{array}{c}-0.0391 \\
{[0.0388]}\end{array}$ \\
\hline LEVEL: ACCOUNT & $(+)$ & $\begin{array}{c}-0.0012 \\
{[0.0016]}\end{array}$ & $\begin{array}{c}0.0106 \\
{[0.0052]^{* *}}\end{array}$ & $\begin{array}{c}0.0030 \\
{[0.0033]}\end{array}$ & $\begin{array}{c}0.0048 \\
{[0.0061]}\end{array}$ & $\begin{array}{c}-0.0017 \\
{[0.0026]}\end{array}$ & $\begin{array}{c}0.0084 \\
{[0.0079]}\end{array}$ & $\begin{array}{c}0.0045 \\
{[0.0047]}\end{array}$ & $\begin{array}{c}0.0113 \\
{[0.0098]}\end{array}$ \\
\hline $\begin{array}{l}\text { INTERACTION: } \\
\text { ACCOUNT x Fin. Opn. [t-5] }\end{array}$ & $(+)$ & $\begin{array}{l}-0.0011 \\
{[0.0012]}\end{array}$ & $\begin{array}{c}0.0050 \\
{[0.0031]}\end{array}$ & $\begin{array}{c}0.004 \\
{[0.0025]}\end{array}$ & $\begin{array}{c}0.0016 \\
{[0.0032]}\end{array}$ & $\begin{array}{c}-0.0023 \\
{[0.0018]} \\
\end{array}$ & $\begin{array}{l}-0.0015 \\
{[0.0047]} \\
\end{array}$ & $\begin{array}{c}0.0021 \\
{[0.0027]}\end{array}$ & $\begin{array}{c}0.008 \\
{[0.0062]}\end{array}$ \\
\hline $\mathrm{N}$ & & 200 & 130 & 157 & 129 & 105 & 66 & 77 & 65 \\
\hline Adj. R-sq. & & 0.11 & 0.12 & 0.29 & 0.05 & 0.20 & 0.16 & 0.09 & -0.06 \\
\hline
\end{tabular}

Notes: Heteroskedasticity robust standard errors in parentheses. Dependent variable is the average annual growth rate over a five year period. Financial openness is measured by the Chinn-Ito index $(K A O P E N)$. Regressions include fixed time effects (estimates not reported). Observations of inflation rates in excess of $100 \%$ are dropped from the sample. $(*)[* *]\{* *\}$ indicates marginal significance at the $(10 \%)[5 \%]\{1 \%\}$ level. 


\section{Table 6: Difference between LDCs and EMGs in terms of the Total effect of a one-unit increase in KAOPEN when the dependent variable is SMTV}

\begin{tabular}{|c|c|c|c|}
\hline & & LDC & EMG \\
\hline$[\mathrm{A}]$ & Total effect of KA Openness & -0.0006 & 0.0041 \\
\hline$[\mathrm{B}]$ & $\bar{L}($ Legall $)$ & -0.74 & -0.28 \\
\hline$[\mathrm{C}]$ & Threshold level of Legall & \multicolumn{2}{|c|}{-0.68} \\
\hline$[\mathrm{A}]$ & Total effect of KA Openness & -0.0017 & 0.0015 \\
\hline [B] & $\bar{L}($ Corrupt $)$ & 49.27 & 54.73 \\
\hline$[\mathrm{C}]$ & Threshold level of Corrupt & \multicolumn{2}{|c|}{52.2} \\
\hline [A] & Total effect of KA Openness & -0.0015 & 0.0005 \\
\hline [B] & $\bar{L}(L A O)$ & 50.85 & 55.76 \\
\hline$[\mathrm{C}]$ & Threshold level of $L A O$ & \multicolumn{2}{|c|}{54.5} \\
\hline [A] & Total effect of KA Openness & 0.0024 & 0.0071 \\
\hline [B] & $\bar{L}(B Q)$ & 48.66 & 56.44 \\
\hline$[\mathrm{C}]$ & Threshold level of $B Q$ & \multicolumn{2}{|c|}{44.7} \\
\hline$[\mathrm{A}]$ & Total effect of KA Openness & 0.0052 & - \\
\hline$[\mathrm{B}]$ & $\bar{L}($ Legal2) & -0.77 & - \\
\hline$[\mathrm{C}]$ & Threshold level of Legal2 & -1.44 & \\
\hline
\end{tabular}

Notes: "Total Effect" [A] indicates the total effect of a one-unit increase in $K A O P E N$ when the legal/institutional variable takes the value of the average in the subsample group ( $\bar{L}$, shown in [B]). The estimation model is based on equation (1) using the data of the LDC subgroup for the regressions with LEGAL1 legal variables and of the LDC/EMG subgroup for the regressions with $L E G A L 2$. Rows [C] show the threshold level of the legal variable above which the capital account openness has a positive impact on financial development. For the analysis with $L E G A L 2$, there is no distinction between LDC and EMG due to data availability, but there is a subgroup LDC/EMG. 
Table 7: Determinants of Capital Account and Trade Openness

FULL, LDC, and EMG: Five year panels, 1980-2000

\begin{tabular}{|c|c|c|c|c|c|c|c|}
\hline \multirow[t]{2}{*}{ Dependent Variable: } & \multirow[b]{2}{*}{\begin{tabular}{|c|} 
Pred. \\
Sign \\
\end{tabular}} & \multicolumn{3}{|c|}{ Financial Openness $(t)$} & \multicolumn{3}{|c|}{ Trade Openness $(t)$} \\
\hline & & $\begin{array}{c}1) \\
\text { Full } \\
\end{array}$ & $\begin{array}{c}(2) \\
\text { LDC } \\
\end{array}$ & $\begin{array}{c}(3) \\
\text { EMG } \\
\end{array}$ & $\begin{array}{c}(4) \\
\text { Full } \\
\end{array}$ & $\begin{array}{c}(5) \\
\text { LDC } \\
\end{array}$ & $\begin{array}{c}(6) \\
\text { EMG } \\
\end{array}$ \\
\hline Financial Openness $(t-5)$ & + & $\begin{array}{c}0.5939 \\
{[0.0580]^{* * *}}\end{array}$ & $\begin{array}{c}0.5313 \\
{[0.0794]^{* * *}}\end{array}$ & $\begin{array}{c}0.3499 \\
{[0.1176]^{* * *}}\end{array}$ & $\begin{array}{l}-0.0001 \\
{[0.0015]}\end{array}$ & $\begin{array}{c}0.0019 \\
{[0.0022]}\end{array}$ & $\begin{array}{l}-0.0005 \\
{[0.0028]}\end{array}$ \\
\hline Trade Openness $(t-5)$ & + & $\begin{array}{c}2.1763 \\
{[1.0279]^{* *}}\end{array}$ & $\begin{array}{c}2.0317 \\
{[1.0586]^{* *}}\end{array}$ & $\begin{array}{c}1.9427 \\
{[2.0338]}\end{array}$ & $\begin{array}{c}0.5938 \\
{[0.0794]^{* * *}}\end{array}$ & $\begin{array}{c}0.5633 \\
{[0.0857]^{* * *}}\end{array}$ & $\begin{array}{c}0.5746 \\
{[0.0940]^{* * *}}\end{array}$ \\
\hline Avg. Budget Sur & + & $\begin{array}{c}0.0402 \\
{[0.0151]^{* * *}}\end{array}$ & $\begin{array}{c}0.0537 \\
{[0.0177]^{* * *}}\end{array}$ & $\begin{array}{c}0.0618 \\
{[0.0305]^{* *}}\end{array}$ & $\begin{array}{c}0.0002 \\
{[0.0005]}\end{array}$ & $\begin{array}{c}0.0002 \\
{[0.0007]}\end{array}$ & $\begin{array}{c}0.0002 \\
{[0.0006]}\end{array}$ \\
\hline Avg. Total reserves $(t-1 \mid t-5)$ & + & $\begin{array}{l}-0.0049 \\
{[0.0245]}\end{array}$ & $\begin{array}{c}0.0043 \\
{[0.0304]}\end{array}$ & $\begin{array}{c}0.0124 \\
{[0.0413]}\end{array}$ & & & \\
\hline Avg. GDP per $\mathrm{c}$ & + & $\begin{array}{c}0.3034 \\
{[0.0971]^{* * *}}\end{array}$ & $\begin{array}{c}0.1945 \\
{[0.1157]^{*}}\end{array}$ & $\begin{array}{c}0.5135 \\
{[0.2821]^{*}}\end{array}$ & $\begin{array}{c}0.0174 \\
{[0.0035]^{* * *}}\end{array}$ & $\begin{array}{c}0.0196 \\
{[0.0047]^{* * *}}\end{array}$ & $\begin{array}{c}0.0339 \\
{[0.0086]^{* * *}}\end{array}$ \\
\hline Number of Observations & & 263 & 181 & 100 & 223 & 151 & 82 \\
\hline Adjusted $\mathrm{R}^{2}$ & & 0.59 & 0.42 & 0.35 & 0.75 & 0.63 & 0.70 \\
\hline \multicolumn{8}{|c|}{$\begin{array}{l}\text { Notes: Robust standard errors in brackets. * significant at } 10 \% ; * * \text { significant at 5\%; *** significant at } 1 \% \text {. Budget surplus, total } \\
\text { reserves, and GDP per capita are included at the average over } \mathrm{t}-1 \text { through t-5. Constant and regional dummies for Asia, Europe, } \\
\text { Middle East, and Africa are also included in the regression, but their estimated coefficients are not reported. The regression } \\
\text { estimations are conducted in non-overlapping manners with the observations excepted for 1980, 1985, 1990, 1995, and } 2000 \\
\text { excluded. }\end{array}$} \\
\hline
\end{tabular}


Table 8: Two-Stage Least Squares Analysis

Instrumented by per capita output, budget balance, and trade openness I

LEGAL1 (General Legal/Institutional Development)

FULL, LDC, and EMG: Five year panels, 1980-2000

\begin{tabular}{|c|c|c|c|c|c|c|c|c|c|c|c|c|c|}
\hline & & \multicolumn{4}{|c|}{ FULL } & \multicolumn{4}{|c|}{ LDC } & \multicolumn{4}{|c|}{ EMG } \\
\hline & $\begin{array}{c}\text { Pred } \\
\text { sign }\end{array}$ & $\begin{array}{c}\text { Private } \\
\text { Credit } \\
{[1]}\end{array}$ & $\begin{array}{c}\text { Stock Mkt } \\
\text { Capital'n } \\
{[2]} \\
\end{array}$ & $\begin{array}{c}\text { Stock Mkt } \\
\text { Total Value } \\
{[3]}\end{array}$ & $\begin{array}{c}\text { Stock Mkt } \\
\text { Turnover } \\
{[4]} \\
\end{array}$ & $\begin{array}{c}\text { Private } \\
\text { Credit } \\
{[5]}\end{array}$ & $\begin{array}{c}\text { Stock Mkt } \\
\text { Capital'n } \\
{[6]} \\
\end{array}$ & $\begin{array}{c}\text { Stock Mkt } \\
\text { Total Value } \\
{[7]}\end{array}$ & $\begin{array}{c}\text { Stock Mkt } \\
\text { Turnover } \\
{[8]} \\
\end{array}$ & $\begin{array}{c}\text { Private } \\
\text { Credit } \\
\text { [9] }\end{array}$ & $\begin{array}{c}\text { Stock Mkt } \\
\text { Capital'n } \\
{[10]} \\
\end{array}$ & $\begin{array}{c}\text { Stock Mkt } \\
\text { Total Value } \\
{[11]}\end{array}$ & $\begin{array}{c}\text { Stock Mkt } \\
\text { Turnover } \\
{[12]} \\
\end{array}$ \\
\hline \multicolumn{14}{|c|}{ Legal/Inst. Variable: LEGAL1 } \\
\hline $\begin{array}{l}\text { Financial } \\
\text { Openness [t-5] }\end{array}$ & $(+)$ & $\begin{array}{c}0.0024 \\
{[0.0031]}\end{array}$ & $\begin{array}{c}0.0057 \\
{[0.0061]}\end{array}$ & $\begin{array}{c}0.0019 \\
{[0.0051]}\end{array}$ & $\begin{array}{l}-0.0033 \\
{[0.0106]}\end{array}$ & $\begin{array}{c}0.0000 \\
{[0.0033]}\end{array}$ & $\begin{array}{c}0.0186 \\
{[0.0094]^{*}}\end{array}$ & $\begin{array}{c}0.0210 \\
{[0.0075]^{* * *}}\end{array}$ & $\begin{array}{c}0.0079 \\
{[0.0125]}\end{array}$ & $\begin{array}{c}0.0011 \\
{[0.0037]}\end{array}$ & $\begin{array}{c}0.0108 \\
{[0.0074]}\end{array}$ & $\begin{array}{c}0.0172 \\
{[0.0065]^{* *}}\end{array}$ & $\begin{array}{l}-0.0029 \\
{[0.0253]}\end{array}$ \\
\hline $\begin{array}{l}\text { LEVEL: } \\
\qquad L E G A L 1\end{array}$ & $(+)$ & $\begin{array}{c}0.0022 \\
{[0.0015]}\end{array}$ & $\begin{array}{c}0.0041 \\
{[0.0047]}\end{array}$ & $\begin{array}{c}0.0032 \\
{[0.0025]}\end{array}$ & $\begin{array}{l}-0.0053 \\
{[0.0123]}\end{array}$ & $\begin{array}{c}0.0006 \\
{[0.0025]}\end{array}$ & $\begin{array}{c}0.0265 \\
{[0.0092]^{* * *}}\end{array}$ & $\begin{array}{c}0.0116 \\
{[0.0057]^{* *}}\end{array}$ & $\begin{array}{c}-0.0184 \\
{[0.0252]}\end{array}$ & $\begin{array}{c}0.0052 \\
{[0.0042]}\end{array}$ & $\begin{array}{c}0.0198 \\
{[0.0089]^{* *}}\end{array}$ & $\begin{array}{c}0.0088 \\
{[0.0053]^{*}}\end{array}$ & $\begin{array}{l}-0.0213 \\
{[0.0285]}\end{array}$ \\
\hline $\begin{array}{l}\text { INTERACT.: } L E G A L 1 \mathrm{x} \\
\text { Fin. Open. [t-5] }\end{array}$ & $(+)$ & $\begin{array}{c}0.0007 \\
{[0.0010]}\end{array}$ & $\begin{array}{c}0.0030 \\
{[0.0024]}\end{array}$ & $\begin{array}{c}0.0041 \\
{[0.0022]^{*}}\end{array}$ & $\begin{array}{c}0.0061 \\
{[0.0052]}\end{array}$ & $\begin{array}{l}-0.0003 \\
{[0.0015]}\end{array}$ & $\begin{array}{c}0.0043 \\
{[0.0051]}\end{array}$ & $\begin{array}{c}0.0112 \\
{[0.0037]^{* * *}}\end{array}$ & $\begin{array}{c}0.0231 \\
{[0.0142]}\end{array}$ & $\begin{array}{c}0.0036 \\
{[0.0024]}\end{array}$ & $\begin{array}{c}0.0053 \\
{[0.0039]}\end{array}$ & $\begin{array}{c}0.0096 \\
{[0.0032]^{* * *}}\end{array}$ & $\begin{array}{c}0.0223 \\
{[0.0149]}\end{array}$ \\
\hline $\begin{array}{l}\text { Financial } \\
\text { Deepening [t-5] }\end{array}$ & $(-)$ & $\begin{array}{l}-0.0109 \\
{[0.0134]}\end{array}$ & $\begin{array}{l}-0.0426 \\
{[0.0291]}\end{array}$ & $\begin{array}{c}0.0785 \\
{[0.0901]}\end{array}$ & $\begin{array}{c}-0.0447 \\
{[0.0408]}\end{array}$ & $\begin{array}{c}0.0257 \\
{[0.0162]}\end{array}$ & $\begin{array}{c}-0.0805 \\
{[0.0326]^{* *}}\end{array}$ & $\begin{array}{l}-0.1180 \\
{[0.0777]}\end{array}$ & $\begin{array}{l}-0.0196 \\
{[0.0582]}\end{array}$ & $\begin{array}{l}-0.0133 \\
{[0.0246]}\end{array}$ & $\begin{array}{c}-0.0617 \\
{[0.0298]^{* *}}\end{array}$ & $\begin{array}{l}-0.0931 \\
{[0.0665]}\end{array}$ & $\begin{array}{l}-0.0227 \\
{[0.0688]}\end{array}$ \\
\hline Inflation [t-5] & $(-)$ & $\begin{array}{c}-0.0218 \\
{[0.0098]^{* *}}\end{array}$ & $\begin{array}{c}-0.0522 \\
{[0.0223]^{* *}}\end{array}$ & $\begin{array}{c}-0.0053 \\
{[0.0291]}\end{array}$ & $\begin{array}{c}-0.0070 \\
{[0.1005]}\end{array}$ & $\begin{array}{c}-0.005 \\
{[0.0102]}\end{array}$ & $\begin{array}{c}-0.0508 \\
{[0.0293]^{*}}\end{array}$ & $\begin{array}{c}0.0196 \\
{[0.0319]}\end{array}$ & $\begin{array}{c}-0.0028 \\
{[0.1243]}\end{array}$ & $\begin{array}{c}-0.0312 \\
{[0.0160]^{*}}\end{array}$ & $\begin{array}{c}-0.0557 \\
{[0.0279]^{*}}\end{array}$ & $\begin{array}{c}0.0236 \\
{[0.0391]}\end{array}$ & $\begin{array}{l}-0.0437 \\
{[0.2139]}\end{array}$ \\
\hline $\mathrm{N}$ & & 189 & 140 & 152 & 138 & 117 & 77 & 83 & 75 & 70 & 66 & 70 & 65 \\
\hline R-sq. & & 0.17 & 0.14 & 0.27 & 0.09 & 0.17 & 0.29 & 0.04 & 0.10 & 0.28 & 0.36 & 0.10 & 0.15 \\
\hline
\end{tabular}

Notes: Point estimates from OLS, heteroskedasticity robust standard errors in parentheses. Dependent variable is the average annual growth rate over a five year period. Financial openness is measured by the Chinn-Ito index $(K A O P E N)$. Regressions include fixed time effects (estimates not reported). Observations of inflation rates in excess of $100 \%$ are dropped from the sample. $(*)[* *]\{* *\}$ indicates marginal significance at the $(10 \%)[5 \%]\{1 \%\}$ level.

II- The variable for financial openness lagged five years $\left(K A O P E N_{t-5}\right)$ is instrumented by per capita output and budget balance, both of which are included as the average over the five years prior to five years before each window (i.e., t-10 through t-6 since the IV is already lagged five years), regional dummies, and the level of financial openness and trade openness, both of which are lagged ten years. 
Table 9: Order of Financial Liberalization

(LEGAL1,Corruption, Law and Order, and Bureaucracy Quality)

FULL, LDC, and EMG: Five year panels, 1980-2000

\begin{tabular}{|c|c|c|c|c|c|c|c|c|c|c|c|c|c|}
\hline & & \multicolumn{4}{|c|}{ FULL } & \multicolumn{4}{|c|}{ LDC } & \multicolumn{4}{|c|}{ EMG } \\
\hline & $\begin{array}{l}\text { Pred } \\
\text { sign }\end{array}$ & \begin{tabular}{|c} 
Private \\
Credit \\
{$[1]$}
\end{tabular} & $\begin{array}{c}\text { Stock Mkt } \\
\text { Capital'n } \\
{[2]}\end{array}$ & $\begin{array}{c}\text { Stock Mkt } \\
\text { Total Val. } \\
{[3]} \\
\end{array}$ & $\begin{array}{c}\text { Stock Mkt } \\
\text { Turnover } \\
{[4]} \\
\end{array}$ & $\begin{array}{c}\text { Private } \\
\text { Credit } \\
{[5]}\end{array}$ & $\begin{array}{c}\text { Stock Mkt } \\
\text { Capital'n } \\
{[6]}\end{array}$ & $\begin{array}{c}\text { Stock Mkt } \\
\text { Total Val. } \\
{[7]}\end{array}$ & $\begin{array}{c}\text { Stock Mkt } \\
\text { Turnover } \\
{[8]}\end{array}$ & $\begin{array}{c}\text { Private } \\
\text { Credit } \\
\text { [9] }\end{array}$ & $\begin{array}{c}\text { Stock Mkt } \\
\text { Capital'n } \\
{[10]}\end{array}$ & $\begin{array}{c}\text { Stock Mkt } \\
\text { Total Val. } \\
{[11]}\end{array}$ & $\begin{array}{c}\text { Stock Mkt } \\
\text { Turnover } \\
{[12]}\end{array}$ \\
\hline \multicolumn{14}{|c|}{ Legal/Inst. Variable: LEGAL1 (General Level of Legal/Institutional Development) } \\
\hline $\begin{array}{c}\text { Other type of Financial } \\
\text { Development }(t-5)\end{array}$ & $+/-$ & $\begin{array}{c}0.0033 \\
{[0.0064]}\end{array}$ & $\begin{array}{c}0.0282 \\
{[0.0286]}\end{array}$ & $\begin{array}{c}-0.0028 \\
{[0.0336]}\end{array}$ & $\begin{array}{c}0.0133 \\
{[0.0307]}\end{array}$ & $\begin{array}{c}-0.0034 \\
{[0.0070]}\end{array}$ & $\begin{array}{c}0.1306 \\
{[0.0646]^{* *}}\end{array}$ & $\begin{array}{c}0.1040 \\
{[0.0499]^{* *}}\end{array}$ & $\begin{array}{c}0.0624 \\
{[0.0554]}\end{array}$ & $\begin{array}{c}0.0033 \\
{[0.0089]}\end{array}$ & $\begin{array}{c}0.0701 \\
{[0.0710]}\end{array}$ & $\begin{array}{c}0.0861 \\
{[0.0578]}\end{array}$ & $\begin{array}{c}0.0454 \\
{[0.0660]}\end{array}$ \\
\hline $\mathrm{N}$ & & 169 & 169 & 199 & 166 & 97 & 97 & 111 & 94 & 85 & 86 & 96 & 84 \\
\hline Adj. R-sq. & & 0.12 & 0.11 & 0.27 & 0.02 & 0.07 & 0.27 & 0.22 & -0.02 & 0.15 & 0.21 & 0.21 & -0.01 \\
\hline \multicolumn{14}{|c|}{ Legal/Inst. Variable: CORRUPT (Corruption) } \\
\hline $\begin{array}{c}\text { Other type of Financial } \\
\text { Development }(t-5)\end{array}$ & $+/-$ & $\mid \begin{array}{c}0.0025 \\
{[0.0067]}\end{array}$ & $\begin{array}{c}0.0285 \\
{[0.0281]}\end{array}$ & $\begin{array}{c}-0.0031 \\
{[0.0333]}\end{array}$ & $\begin{array}{c}0.0189 \\
{[0.0310]}\end{array}$ & $\begin{array}{l}-0.0046 \\
{[0.0078]}\end{array}$ & $\begin{array}{c}0.1262 \\
{[0.0610]^{* *}}\end{array}$ & $\begin{array}{c}0.1008 \\
{[0.0470]^{* *}}\end{array}$ & $\begin{array}{c}0.0747 \\
{[0.0545]}\end{array}$ & $\begin{array}{c}0.0014 \\
{[0.0099]}\end{array}$ & $\begin{array}{c}0.0641 \\
{[0.0620]}\end{array}$ & $\begin{array}{c}0.0872 \\
{[0.0514]^{*}}\end{array}$ & $\begin{array}{c}0.0746 \\
{[0.0622]}\end{array}$ \\
\hline $\mathrm{N}$ & & 169 & 169 & 199 & 166 & 97 & 97 & 111 & 94 & 85 & 86 & 96 & 84 \\
\hline Adj. R-sq. & & 0.12 & 0.11 & 0.27 & 0.02 & 0.07 & 0.30 & 0.21 & -0.02 & 0.12 & 0.26 & 0.21 & -0.01 \\
\hline \multicolumn{14}{|c|}{ Legal/Inst. Variable: $L A O$ (Law and Order) } \\
\hline $\begin{array}{l}\text { Other type of Financial } \\
\text { Development }(t-5)\end{array}$ & $+/-$ & $\begin{array}{c}0.0039 \\
{[0.0064]}\end{array}$ & $\begin{array}{c}0.0329 \\
{[0.0291]}\end{array}$ & $\begin{array}{l}-0.0023 \\
{[0.0339]}\end{array}$ & $\begin{array}{c}0.0136 \\
{[0.0309]}\end{array}$ & $\begin{array}{l}-0.0008 \\
{[0.0064]}\end{array}$ & $\begin{array}{c}0.142 \\
{[0.0640]^{* *}}\end{array}$ & $\begin{array}{c}0.1023 \\
{[0.0499]^{* *}}\end{array}$ & $\begin{array}{c}0.0484 \\
{[0.0548]}\end{array}$ & $\begin{array}{c}0.0076 \\
{[0.0085]}\end{array}$ & $\begin{array}{c}0.0988 \\
{[0.0708]}\end{array}$ & $\begin{array}{c}0.0925 \\
{[0.0562]}\end{array}$ & $\begin{array}{c}0.0332 \\
{[0.0720]}\end{array}$ \\
\hline $\mathrm{N}$ & & 169 & 169 & 199 & 166 & 97 & 97 & 111 & 94 & 85 & 86 & 96 & 84 \\
\hline Adj. R-sq. & & 0.11 & 0.12 & 0.27 & 0.01 & 0.08 & 0.29 & 0.17 & -0.04 & 0.12 & 0.23 & 0.16 & -0.02 \\
\hline \multicolumn{14}{|c|}{ Legal/Inst. Variable: $B Q$ (Bureaucracy Quality) } \\
\hline $\begin{array}{l}\text { Other type of Financial } \\
\text { Development }(t-5)\end{array}$ & $+1-$ & $\begin{array}{c}0.0026 \\
{[0.0066]}\end{array}$ & $\begin{array}{c}0.0269 \\
{[0.0288]}\end{array}$ & $\begin{array}{l}-0.0050 \\
{[0.0337]}\end{array}$ & $\begin{array}{c}0.0102 \\
{[0.0317]}\end{array}$ & $\begin{array}{l}-0.0025 \\
{[0.0070]}\end{array}$ & $\begin{array}{c}0.1292 \\
{[0.0615]^{* *}}\end{array}$ & $\begin{array}{c}0.0982 \\
{[0.0532]^{*}}\end{array}$ & $\begin{array}{c}0.0397 \\
{[0.0582]}\end{array}$ & $\begin{array}{c}0.0032 \\
{[0.0103]}\end{array}$ & $\begin{array}{c}0.0776 \\
{[0.0607]}\end{array}$ & $\begin{array}{c}0.0684 \\
{[0.0572]}\end{array}$ & $\begin{array}{c}0.0238 \\
{[0.0702]}\end{array}$ \\
\hline $\mathrm{N}$ & & 169 & 169 & 199 & 166 & 97 & 97 & 111 & 94 & 85 & 86 & 96 & 84 \\
\hline Adj. R-sq. & & 0.12 & 0.10 & 0.26 & 0.01 & 0.06 & 0.25 & 0.21 & -0.02 & 0.08 & 0.17 & 0.19 & 0.01 \\
\hline
\end{tabular}

Notes: Point estimates from OLS, heteroskedasticity robust standard errors in parentheses. Dependent variable is the average annual growth rate over a five year period. Financial openness is measured by the Chinn-Ito index (KAOPEN). Regressions include fixed time effects (estimates not reported).

Observations of inflation rates in excess of $100 \%$ are dropped from the sample. $(*)[* *]\{* * *\}$ indicates marginal significance at the $(10 \%)[5 \%]\{1 \%\}$ level. 
Table 10: Relationship between Different Types of Financial Development

(Controlled for LEGAL1, Corruption, Law and Order, and Bureaucracy Quality)

FULL, LDC, and EMG: Five year panels, 1980-2000

\begin{tabular}{|c|c|c|c|c|c|c|c|c|c|c|c|c|c|}
\hline & & \multicolumn{4}{|c|}{ FULL } & \multicolumn{4}{|c|}{ LDC } & \multicolumn{4}{|c|}{ EMG } \\
\hline & $\begin{array}{c}\text { Pred } \\
\text { sign }\end{array}$ & \begin{tabular}{|c} 
Private \\
Credit \\
{$[1]$}
\end{tabular} & $\begin{array}{c}\text { Stock Mkt } \\
\text { Capital'n } \\
{[2]} \\
\end{array}$ & $\begin{array}{c}\text { Stock Mkt } \\
\text { Total Val. } \\
{[3]} \\
\end{array}$ & $\begin{array}{c}\text { Stock Mkt } \\
\text { Turnover } \\
{[4]}\end{array}$ & $\begin{array}{c}\text { Private } \\
\text { Credit } \\
{[5]}\end{array}$ & $\begin{array}{c}\text { Stock Mkt } \\
\text { Capital'n } \\
{[6]} \\
\end{array}$ & $\begin{array}{c}\text { Stock Mkt } \\
\text { Total Val. } \\
\text { [7] } \\
\end{array}$ & $\begin{array}{c}\text { Stock Mkt } \\
\text { Turnover } \\
{[8]}\end{array}$ & $\begin{array}{c}\text { Private } \\
\text { Credit } \\
{[9]}\end{array}$ & $\begin{array}{c}\text { Stock Mkt } \\
\text { Capital'n } \\
{[10]}\end{array}$ & $\begin{array}{c}\text { Stock Mkt } \\
\text { Total Val. } \\
{[11]} \\
\end{array}$ & $\begin{array}{c}\text { Stock Mk } \\
\text { Turnover } \\
{[12]}\end{array}$ \\
\hline \multicolumn{14}{|c|}{ Legal/Inst. Variable: LEGAL1 (General Level of Legal/Institutional Development) } \\
\hline $\begin{array}{l}\text { Other type of Financial } \\
\text { Development }(t \mid t-5)\end{array}$ & $+1-$ & $\begin{array}{c}0.0410 \\
{[0.0504]}\end{array}$ & $\begin{array}{c}0.1769 \\
{[0.2149]}\end{array}$ & $\begin{array}{c}0.0443 \\
{[0.1745]}\end{array}$ & $\begin{array}{l}-0.1059 \\
{[0.2432]}\end{array}$ & $\mid \begin{array}{c}0.0910 \\
{[0.0402]^{* *}}\end{array}$ & $\begin{array}{c}0.7073 \\
{[0.2446]^{* * *}}\end{array}$ & $\begin{array}{c}0.5069 \\
{[0.3314]}\end{array}$ & $\begin{array}{l}-0.1026 \\
{[0.6457]}\end{array}$ & $\begin{array}{c}0.0609 \\
{[0.0440]}\end{array}$ & $\begin{array}{c}0.4044 \\
{[0.2111]^{*}}\end{array}$ & $\begin{array}{c}0.3362 \\
{[0.3061]}\end{array}$ & $\begin{array}{l}-0.2559 \\
{[0.7226]}\end{array}$ \\
\hline $\mathrm{N}$ & & 165 & 165 & 195 & 162 & 93 & 93 & 107 & 90 & 84 & 84 & 94 & 82 \\
\hline Adj. R-sq. & & 0.12 & 0.10 & 0.27 & 0.02 & 0.13 & 0.24 & 0.18 & -0.03 & 0.17 & 0.2 & 0.18 & -0.01 \\
\hline \multicolumn{14}{|c|}{ Legal//nst. Variable: Corrupt (Corruption) } \\
\hline $\begin{array}{l}\text { Other type of Financial } \\
\text { Development }(t \mid t-5)\end{array}$ & $+1-$ & $\begin{array}{c}0.0385 \\
{[0.0502]}\end{array}$ & $\begin{array}{c}0.1614 \\
{[0.2186]}\end{array}$ & $\begin{array}{c}0.0403 \\
{[0.1758]}\end{array}$ & $\begin{array}{l}-0.0887 \\
{[0.2468]}\end{array}$ & {$\left[\begin{array}{c}0.0893 \\
{[0.0405]^{* *}}\end{array}\right.$} & $\begin{array}{c}0.6745 \\
{[0.2572]^{* *}}\end{array}$ & $\begin{array}{c}0.4858 \\
{[0.3346]}\end{array}$ & $\begin{array}{l}-0.1425 \\
{[0.6512]}\end{array}$ & $\begin{array}{c}0.0559 \\
{[0.0453]}\end{array}$ & $\begin{array}{c}0.3538 \\
{[0.2225]}\end{array}$ & $\begin{array}{c}0.3605 \\
{[0.3242]}\end{array}$ & $\begin{array}{l}-0.0175 \\
{[0.6922]}\end{array}$ \\
\hline $\mathrm{N}$ & & 165 & 165 & 195 & 162 & 93 & 93 & 107 & 90 & 84 & 84 & 94 & 82 \\
\hline Adj. R-sq. & & 0.13 & 0.10 & 0.27 & 0.02 & 0.12 & 0.26 & 0.17 & -0.03 & 0.14 & 0.24 & 0.18 & -0.02 \\
\hline \multicolumn{14}{|c|}{ Legal/Inst. Variable: $L A O$ (Law and Order) } \\
\hline $\begin{array}{l}\text { Other type of Financial } \\
\text { Development }(t \mid t-5)\end{array}$ & $+1-$ & $\begin{array}{c}0.0403 \\
{[0.0499]}\end{array}$ & $\begin{array}{c}0.1701 \\
{[0.2135]}\end{array}$ & $\begin{array}{c}0.0394 \\
{[0.1743]}\end{array}$ & $\begin{array}{c}-0.1102 \\
{[0.2397]}\end{array}$ & $\mid \begin{array}{c}0.0934 \\
{[0.0411]^{* *}}\end{array}$ & $\begin{array}{c}0.7617 \\
{[0.2352]^{* * *}}\end{array}$ & $\begin{array}{c}0.5088 \\
{[0.3244]}\end{array}$ & $\begin{array}{c}-0.0498 \\
{[0.5951]}\end{array}$ & $\begin{array}{c}0.0630 \\
{[0.0443]}\end{array}$ & $\begin{array}{c}0.4332 \\
{[0.2055]^{* *}}\end{array}$ & $\begin{array}{c}0.4339 \\
{[0.3160]}\end{array}$ & $\begin{array}{l}-0.1560 \\
{[0.7124]}\end{array}$ \\
\hline $\mathrm{N}$ & & 165 & 165 & 195 & 162 & 93 & 93 & 107 & 90 & 84 & 84 & 94 & 82 \\
\hline Adj. R-sq. & & 0.12 & 0.11 & 0.27 & 0.01 & 0.14 & 0.25 & 0.13 & -0.04 & 0.15 & 0.20 & 0.14 & -0.03 \\
\hline \multicolumn{14}{|c|}{ Legal/Inst. Variable: $B Q$ (Bureaucracy Quality) } \\
\hline $\begin{array}{l}\text { Other type of Financial } \\
\text { Development }(t \mid t-5)\end{array}$ & $+/-$ & $\mid \begin{array}{c}0.0427 \\
{[0.0501]}\end{array}$ & $\begin{array}{c}0.1862 \\
{[0.2133]}\end{array}$ & $\begin{array}{c}0.0525 \\
{[0.1724]}\end{array}$ & $\begin{array}{c}-0.1068 \\
{[0.2384]}\end{array}$ & {$\left[\begin{array}{c}0.0872 \\
{[0.0414]^{* *}}\end{array}\right.$} & $\begin{array}{c}0.7163 \\
{[0.2353]^{* * *}}\end{array}$ & $\begin{array}{c}0.4693 \\
{[0.3267]}\end{array}$ & $\begin{array}{l}-0.1257 \\
{[0.6790]}\end{array}$ & $\begin{array}{c}0.0856 \\
{[0.0515]}\end{array}$ & $\begin{array}{c}0.5783 \\
{[0.1907]^{* * *}}\end{array}$ & $\begin{array}{c}0.4021 \\
{[0.2379]^{*}}\end{array}$ & $\begin{array}{l}-0.1157 \\
{[0.5846]}\end{array}$ \\
\hline $\mathrm{N}$ & & 165 & 165 & 195 & 162 & 93 & 93 & 107 & 90 & 84 & 84 & 94 & 82 \\
\hline Adj. R-sq. & & 0.12 & 0.09 & 0.26 & 0.01 & 0.12 & 0.22 & 0.18 & -0.03 & 0.12 & 0.18 & 0.18 & 0.01 \\
\hline
\end{tabular}

Notes: Point estimates from OLS, heteroskedasticity robust standard errors in parentheses. Dependent variable is the average annual growth rate over a five year period. Financial openness is measured by the Chinn-Ito index (KAOPEN). Regressions include fixed time effects (estimates not reported).

Observations of inflation rates in excess of $100 \%$ are dropped from the sample. $\left(^{*}\right)[* *]\{* * *\}$ indicates marginal significance at the $(10 \%)[5 \%]\{1 \%\}$ level. 
Figure 1: Correlation between the Change in KAOPEN and the change in SMTV (with a five-year lag)

(a) When LEGAL1 is greater than the threshold hold level

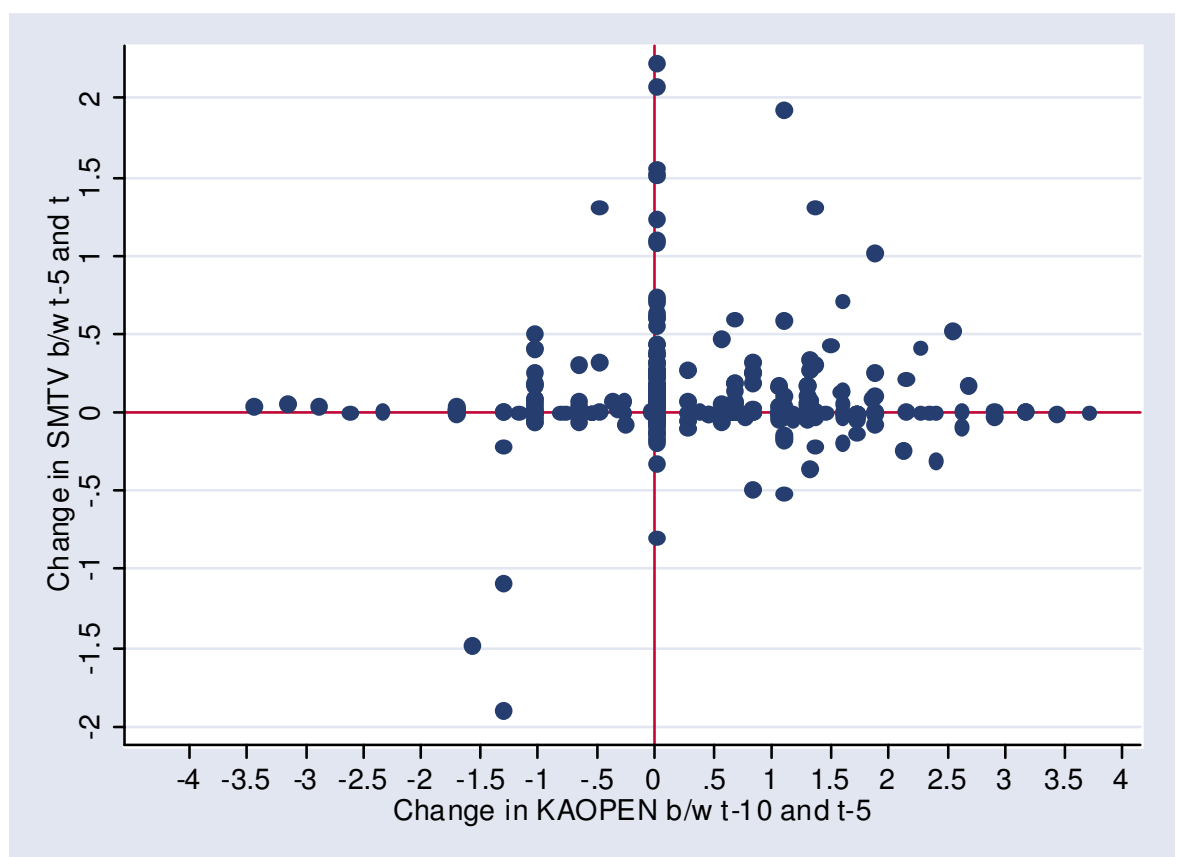

(b) When LEGAL1 is below the threshold hold level

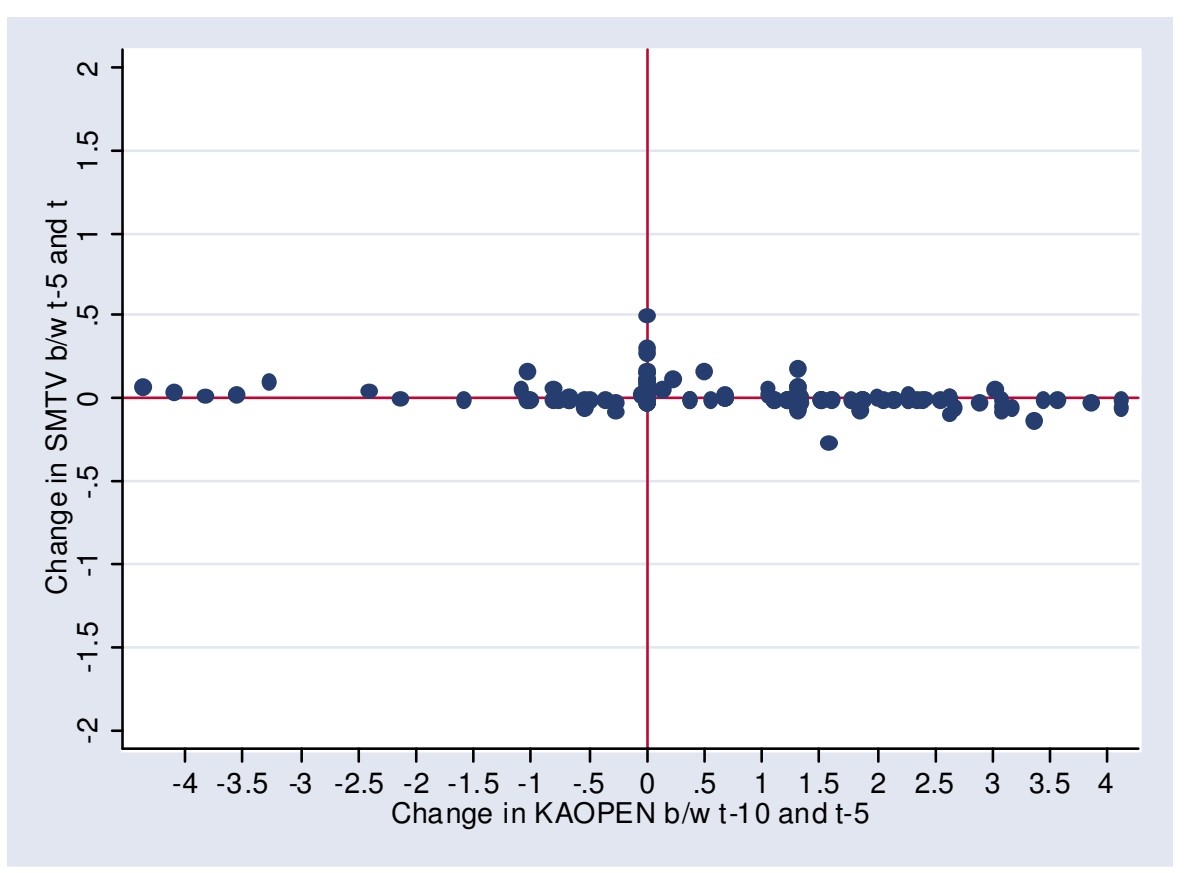

